\title{
Using Stereoelectronic Effects to Explain Selective Reactions of 4-Substituted Five- Membered Ring Oxocarbenium Ions
}

\author{
Deborah M. Smith and K. A. Woerpel* \\ Department of Chemistry, University of California \\ Irvine, CA 92697-2025
}

\section{Supporting Information}

\section{Contents:}

I. Synthesis of the acetate substrates $\quad S-1$

II. Nucleophilic substitution of acetate substrates $\quad S-4$

III. Stereochemical proofs of nucleophilic substituted products $S-7$

IV. Bibliography $\quad S-11$

V. Analytical Data $\quad S-12$

General. ${ }^{1} \mathrm{H}$ NMR and ${ }^{13} \mathrm{C}$ NMR spectra were recorded at ambient temperature at $500 \mathrm{MHz}$ and $125 \mathrm{MHz}$, respectively, using a Bruker DRX 400 or DRX 500 spectrometer. The data are reported as follows: chemical shift in ppm from internal tetramethylsilane on the $\delta$ scale, multiplicity $(b r=$ broad, $\mathrm{s}=$ singlet, $\mathrm{d}=\mathrm{doublet}, \mathrm{t}=$ triplet, $\mathrm{q}=$ quartet, $\mathrm{m}=$ multiplet $)$, coupling constants $(\mathrm{Hz})$, and integration. Infrared (IR) spectra were obtained using a MIDAC Prospect FT-IR spectrometer. High resolution mass spectra were acquired on a VG Analytical $7070 \mathrm{E}$ or Fisons Autospec spectrometer, and were obtained by peak matching. Microanalyses were performed by Atlantic Microlab, Atlanta, GA. Analytical gas-liquid chromatography (GC) analyses were performed on a Hewlett Packard 5890 Level 4 Chromatograph, equipped with a split-mode injection system and a flame ionization detector. A fused silica capillary column $(30 \mathrm{~m} \times 0.32 \mathrm{~mm})$ wall-coated with DB-1 (J \& W Scientific) was used with helium as the carrier gas (16 psi column head pressure). Melting points are reported uncorrected. Liquid chromatography was performed using forced flow (flash chromatography) of the indicated solvent system on EM Reagents silica gel $\left(\mathrm{SiO}_{2}\right) 60$ (230-400 mesh). All reactions were carried out under an atmosphere of nitrogen in glassware that had been flame-dried under a stream of nitrogen. Unless otherwise noted, all reagents were commercially obtained and, where appropriate, purified prior to use. $\mathrm{THF}_{2} \mathrm{Et}_{2} \mathrm{O}$, and $\mathrm{CH}_{2} \mathrm{Cl}_{2}$ were dried by filtration through alumina according to the procedure of Grubbs. ${ }^{1}$

\section{Synthesis of the acetate substrates}

General Procedure for Reduction and Acylation of $\boldsymbol{\gamma}$-Lactones. ${ }^{2}$ To a cooled $\left(-78{ }^{\circ} \mathrm{C}\right)$ solution of $\boldsymbol{\gamma}$ lactone ${ }^{3}$ in $\mathrm{CH}_{2} \mathrm{Cl}_{2}(0.10-0.20 \mathrm{M})$ was added DIBAL-H (1.2 equiv, $1.5 \mathrm{M}$ in toluene). After the mixture was stirred at $-78{ }^{\circ} \mathrm{C}$ for $2 \mathrm{~h}$, pyridine (4.0 equiv) and DMAP (1.2 equiv) were added, followed by the dropwise addition of $\mathrm{Ac}_{2} \mathrm{O}$ (5.0 equiv). After the reaction mixture was allowed to warm to $22{ }^{\circ} \mathrm{C}$ over $12 \mathrm{~h}, 5 \mathrm{~mL}$ of saturated aqueous $\mathrm{NH}_{4} \mathrm{Cl}$ was added and the reaction mixture was concentrated in vacuo. The remaining oil was dissolved in MTBE $(0.050 \mathrm{M})$. The organic layer was washed with $4 \times 10 \mathrm{~mL}$ of saturated aqueous $\mathrm{Na}_{2} \mathrm{HPO}_{4}, 4 \times 10 \mathrm{~mL}$ of saturated aqueous $\mathrm{NaH}_{2} \mathrm{PO}_{4}$, and $5 \times 10 \mathrm{~mL}$ of saturated aqueous $\mathrm{CuSO}_{4}$. The organic phase was dried $\left(\mathrm{Na}_{2} \mathrm{SO}_{4}\right)$ and concentrated in vacuo to provide a dark orange residue. 


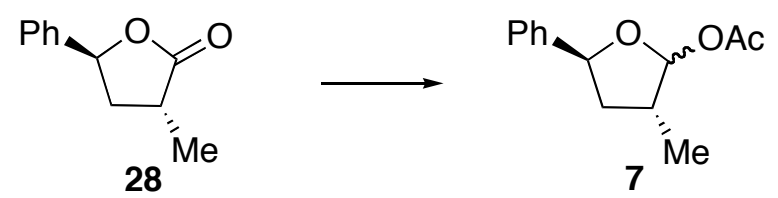

$\left(2 R^{*}, 4 S^{*}\right)$-1-Acetoxy-2-methyl-4-phenyltetrahydrofuran (7). The standard reductive acylation procedure was followed with lactone $\mathbf{2 8}^{3}(0.175 \mathrm{~g}, 0.990 \mathrm{mmol})$ in $5 \mathrm{~mL}$ of $\mathrm{CH}_{2} \mathrm{Cl}_{2}$, with DIBAL-H $(0.79 \mathrm{~mL}$, $1.2 \mathrm{mmol})$, pyridine $(0.320 \mathrm{~mL}, 3.97 \mathrm{mmol})$, DMAP $(0.146 \mathrm{~g}, 1.19 \mathrm{mmol})$, and $\mathrm{Ac}_{2} \mathrm{O}(0.469 \mathrm{~mL}, 4.97 \mathrm{mmol})$. ${ }^{1} \mathrm{H}$ NMR spectroscopic analysis of the unpurified product showed a pair of diastereomers in a ratio of 80:20. Purification by flash chromatography $(0: 100-2: 98$ EtOAc/hexanes) yielded acetate 7 as a colorless oil (0.207 $\mathrm{g}, 89 \%)$. The purified product was characterized as a mixture of diastereomers: ${ }^{1} \mathrm{H} \mathrm{NMR}\left(500 \mathrm{MHz}, \mathrm{CDCl}_{3}\right) \delta$ $7.26-7.36(\mathrm{~m}, 6.5 \mathrm{H}), 6.46(\mathrm{~d}, J=4.6,0.3 \mathrm{H}), 6.09(\mathrm{~s}, 1 \mathrm{H}), 5.36(\mathrm{dd}, J=9.0,3.0,0.3 \mathrm{H}), 5.28(\mathrm{dd}, J=9.8,6.6$, $1 \mathrm{H}), 2.50(\mathrm{~m}, 1.3 \mathrm{H}), 2.07-2.20(\mathrm{~m}, 6.8 \mathrm{H}), 1.18(\mathrm{~d}, J=7.3,3 \mathrm{H}), 1.07(\mathrm{~d}, J=6.8,0.8 \mathrm{H}) ;{ }^{13} \mathrm{C} \mathrm{NMR}(125 \mathrm{MHz}$, $\left.\mathrm{CDCl}_{3}\right) \delta 170.6,142.7,128.6,128.5,127.7,127.5,126.1,125.5,104.1,100.0,82.5,80.9,40.5,39.6,39.2,36.7$, 21.7, 21.5, 16.4, 12.7; IR (thin film) 3035, 2964, 1740, 1237, $902 \mathrm{~cm}^{-1}$; HRMS (GC-MS, EI) $\mathrm{m} / z$ calcd for $\mathrm{C}_{11} \mathrm{H}_{13} \mathrm{O}_{2}\left(\mathrm{M}-\mathrm{C}_{2} \mathrm{H}_{3} \mathrm{O}\right)^{+}$177.0915, found 177.0918. Anal. Calcd for $\mathrm{C}_{13} \mathrm{H}_{16} \mathrm{O}_{3}: \mathrm{C}, 70.89 ; \mathrm{H}, 7.32$. Found: C, $70.90 ; \mathrm{H}, 7.26$.

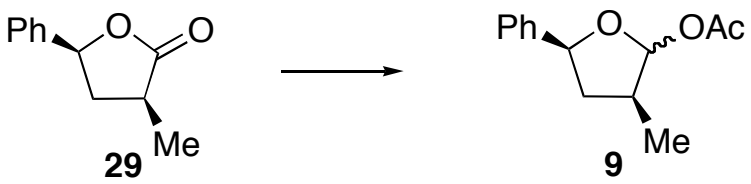

$\left(2 S^{*}, 4 S^{*}\right)$-1-Acetoxy-2-methyl-4-phenyltetrahydrofuran (9). The standard reductive acylation procedure was followed with lactone $29^{3}(0.422 \mathrm{~g}, 2.39 \mathrm{mmol})$ in $15 \mathrm{~mL}$ of $\mathrm{CH}_{2} \mathrm{Cl}_{2}$ with DIBAL-H (1.9 mL, $2.9 \mathrm{mmol})$, pyridine $(0.78 \mathrm{~mL}, 9.6 \mathrm{mmol})$, DMAP $(0.356 \mathrm{~g}, 2.87 \mathrm{mmol})$, and $\mathrm{Ac}_{2} \mathrm{O}(1.13 \mathrm{~mL}, 12.0 \mathrm{mmol})$. ${ }^{1} \mathrm{H}$ NMR spectroscopic analysis of the unpurified product showed a pair of diastereomers in a ratio of 68:32. Purification by flash chromatography $(0: 100-2: 98$ EtOAc/hexanes) yielded acetate 9 as a colorless oil (0.365 g, 69\%). The two diastereomers were separable in small amounts with careful chromatography. Elemental analysis, HRMS, and IR data were obtained for 9 as a mixture of diastereomers. IR (thin film) 3031, 2970, 1745, 1236, $904 \mathrm{~cm}^{-1}$; HRMS (GC-MS, EI) $\mathrm{m} / z$ calcd for $\mathrm{C}_{11} \mathrm{H}_{13} \mathrm{O}_{2}\left(\mathrm{M}-\mathrm{C}_{2} \mathrm{H}_{3} \mathrm{O}\right)^{+}$177.0915, found 177.0911. Anal. Calcd for $\mathrm{C}_{13} \mathrm{H}_{16} \mathrm{O}_{3}$ : C, 70.89; $\mathrm{H}, 7.32$. Found: C, 70.96; H, 7.36.

Major diastereomer of 9. ${ }^{1} \mathrm{H} \operatorname{NMR}\left(500 \mathrm{MHz}, \mathrm{CDCl}_{3}\right) \delta 7.25-7.37(\mathrm{~m}, 5 \mathrm{H}), 6.11(\mathrm{~d}, J=2.4,1 \mathrm{H}), 5.22(\mathrm{dd}, J=$ 9.1, 6.6, 1H), $2.61(\mathrm{~m}, 1 \mathrm{H}), 2.49(\mathrm{~m}, 1 \mathrm{H}), 2.1(\mathrm{~s}, 3 \mathrm{H}), 1.53(\mathrm{~m}, 1 \mathrm{H}), 1.17(\mathrm{~d}, J=7.1,3 \mathrm{H}) ;{ }^{13} \mathrm{C} \mathrm{NMR}(125 \mathrm{MHz}$, $\left.\mathrm{CDCl}_{3}\right) \delta 170.8,141.4,128.6,127.8,126.0,104.8,81.9,41.7,40.8,21.6,18.3$.

Minor diastereomer of 9. ${ }^{1} \mathrm{H} \mathrm{NMR}\left(500 \mathrm{MHz}, \mathrm{CDCl}_{3}\right) \delta 7.25-7.36(\mathrm{~m}, 5 \mathrm{H}), 6.32(\mathrm{~d}, J=4.6,1 \mathrm{H}), 5.11(\mathrm{dd}, J=$ $10.6,6.1,1 \mathrm{H}), 2.52(\mathrm{~m}, 1 \mathrm{H}), 2.42(\mathrm{~m}, 1 \mathrm{H}), 2.12(\mathrm{~s}, 3 \mathrm{H}), 1.74(\mathrm{td}, J=12.5,10.6,1 \mathrm{H}), 1.09(\mathrm{~d}, J=6.7,3 \mathrm{H}) ;{ }^{13} \mathrm{C}$ $\operatorname{NMR}\left(125 \mathrm{MHz}, \mathrm{CDCl}_{3}\right) \delta 170.7,142.6,128.6,127.7,126.1,99.6,83.3,40.3,39.6,21.6,12.5$.

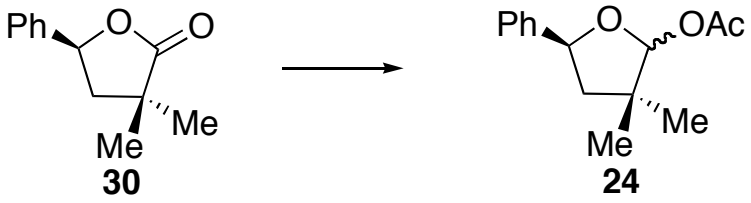

1-Acetoxy-2,2-dimethyl-4-phenyltetrahydrofuran (24). The standard reductive acylation procedure was followed with lactone $\mathbf{3 0}^{4}(0.500 \mathrm{~g}, 2.62 \mathrm{mmol})$ in $25 \mathrm{~mL}$ of $\mathrm{CH}_{2} \mathrm{Cl}_{2}$ with DIBAL-H $(2.10 \mathrm{~mL}, 3.14 \mathrm{mmol})$, pyridine $(0.850 \mathrm{~mL}, 10.5 \mathrm{mmol})$, DMAP $(0.385 \mathrm{~g}, 3.14 \mathrm{mmol})$, and $\mathrm{Ac}_{2} \mathrm{O}(1.24 \mathrm{~mL}, 13.1 \mathrm{mmol})$. GC and ${ }^{1} \mathrm{H}$ NMR spectroscopic analysis of the unpurified product showed a pair of diastereomers in a ratio of 62:38. 
Purification by flash chromatography $(0: 100$ - 2:98 EtOAc/hexanes) yielded acetate 24 as a colorless oil (0.615 $\mathrm{g}, 81 \%)$. The purified product was characterized as a mixture of diastereomers: ${ }^{1} \mathrm{H} \mathrm{NMR}\left(500 \mathrm{MHz} \mathrm{CDCl}{ }_{3}\right) \delta$ $7.23-7.36(\mathrm{~m}, 7.8 \mathrm{H}), 6.10(\mathrm{~s}, 1 \mathrm{H}), 6.00(\mathrm{~s}, 0.6 \mathrm{H}), 5.34(\mathrm{dd}, J=8.8,6.4,1 \mathrm{H}), 5.23(\mathrm{dd}, J=10.5,6.4,0.6 \mathrm{H}), 2.36$ $(\mathrm{dd}, J=12.4,8.7,1 \mathrm{H}), 2.11(\mathrm{~s}, 5 \mathrm{H}$ and $\mathrm{m}, 0.6 \mathrm{H}), 1.90(\mathrm{~m}, 0.6 \mathrm{H}), 1.81(\mathrm{dd}, J=12.5,6.4,1 \mathrm{H}), 1.23(\mathrm{~s}, 1.8 \mathrm{H})$, $1.14(\mathrm{~s}, 3 \mathrm{H}), 1.12$ (s, 3H), $1.11(\mathrm{~s}, 1.8 \mathrm{H}) ;{ }^{13} \mathrm{C} \mathrm{NMR}\left(125 \mathrm{MHz}, \mathrm{CDCl}_{3}\right) \delta 170.62,170.58,142.9,142.2,128.6$, 128.5, 127.6, 127.4, 126.1, 125.6, 104.5, 103.9, 82.4, 80.5, 46.7, 46.3, 44.3, 43.4, 27.8, 24.8, 22.6, 21.9, 21.6, 21.5; IR (thin film) 3030, 2967, 1740, $1374 \mathrm{~cm}^{-1}$; HRMS (GC-MS, EI) $m / z$ calcd for $\mathrm{C}_{14} \mathrm{H}_{18} \mathrm{O}_{3}\left(\mathrm{M}^{+}\right) 234.1256$, found 234.1254. Anal. Calcd for $\mathrm{C}_{14} \mathrm{H}_{18} \mathrm{O}_{3}$ : C, 71.77; H, 7.74. Found: C, 71.71; H, 7.81.
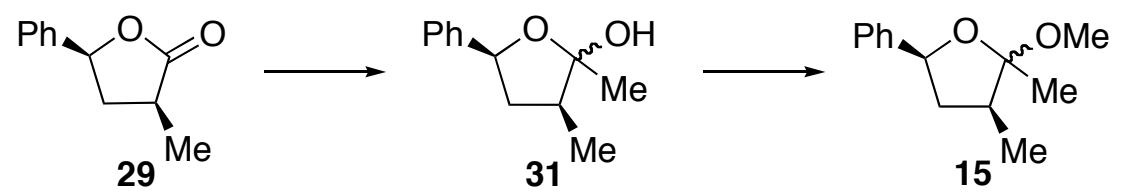

$\left(2 S^{*}, \mathbf{4} S^{*}\right)$-1-Methoxy-1,2-dimethyl-4-phenyltetrahydrofuran (15). ${ }^{5}$ Cerium chloride $\left(\mathrm{CeCl}_{3} \cdot 7 \mathrm{H}_{2} \mathrm{O}\right)$ $(2.48 \mathrm{~g}, 6.68 \mathrm{mmol})$, ground to a fine powder, was heated to $140{ }^{\circ} \mathrm{C}$ with evacuation $(133 \mathrm{~Pa})$. After $1 \mathrm{~h}$, the cerium chloride was cooled to $22{ }^{\circ} \mathrm{C}$ and placed under an atmosphere of nitrogen. A solution of lactone $\mathbf{2 9}^{3}$ $(0.471 \mathrm{~g}, 2.67 \mathrm{mmol})$ in $30 \mathrm{~mL}$ of THF was added and the mixture was stirred for $1 \mathrm{~h}$ at $22{ }^{\circ} \mathrm{C}$. The reaction mixture was cooled to $-45^{\circ} \mathrm{C}$ and methylmagnesium bromide $\left(2.1 \mathrm{~mL}, 6.4 \mathrm{mmol}, 3.0 \mathrm{M}\right.$ in $\left.\mathrm{Et}_{2} \mathrm{O}\right)$ was added. After $1 \mathrm{~h}$ at $-45^{\circ} \mathrm{C}$, the reaction mixture was treated with $15 \mathrm{~mL}$ of $\mathrm{H}_{2} \mathrm{O}$ and warmed to $22{ }^{\circ} \mathrm{C}$. The reaction mixture was filtered through a pad of Celite and extracted with $3 \times 20 \mathrm{~mL}$ of $\mathrm{Et}_{2} \mathrm{O}$. The combined organic phases were dried $\left(\mathrm{Na}_{2} \mathrm{SO}_{4}\right)$ and concentrated in vacuo. ${ }^{1} \mathrm{H}$ NMR spectroscopic analysis of the unpurified product showed the anomeric lactols in a ratio of 74:26, as well as the acyclic carbonyl (32\%). Purification by flash chromatography $\left(0: 100-20: 80 \mathrm{EtOAc} / \mathrm{CH}_{2} \mathrm{Cl}_{2}\right)$ yielded 31 as a colorless oil $(0.437 \mathrm{~g}, 85 \%)$. Due to the instability of the lactol substrate, 31 was converted to methyl acetal 15. A solution of lactol $\mathbf{3 1}(0.387 \mathrm{~g}, 2.01$ $\mathrm{mmol}$ ) in $5.75 \mathrm{~mL}$ of a $0.1 \%$ solution of $\mathrm{HCl}$ in methanol was stirred for $25 \mathrm{~min}$. The reaction mixture was treated with $\mathrm{Ag}_{2} \mathrm{CO}_{3}$, filtered through a pad of Celite, and concentrated in vacuo. ${ }^{1} \mathrm{H}$ NMR spectroscopic analysis of the unpurified product showed a pair of diastereomers in a ratio of 70:30. Purification by flash chromatography (5:95 EtOAc/hexanes) provided 15 as a colorless oil $(0.298 \mathrm{~g}, 72 \%)$. The two diastereomers were separable in small amounts with careful chromatography. Elemental analysis, HRMS, and IR data were obtained for 15 as a mixture of diastereomers: IR (thin film) 2967, 2878, 1450, $1072 \mathrm{~cm}^{-1}$; HRMS (GC-MS, EI) $m / z$ calcd for $\mathrm{C}_{13} \mathrm{H}_{17} \mathrm{O}_{2}(\mathrm{M}-\mathrm{H})^{+}$205.1229, found 205.1229. Anal. Calcd for $\mathrm{C}_{13} \mathrm{H}_{18} \mathrm{O}_{2}: \mathrm{C}, 75.69 ; \mathrm{H}, 8.80$. Found: C, 75.73; H, 8.96.

Major diastereomer of 15. ${ }^{1} \mathrm{H}$ NMR $\left(400 \mathrm{MHz}^{\mathrm{CDCl}}{ }_{3}\right) \delta 7.24-7.36(\mathrm{~m}, 5 \mathrm{H}), 4.98(\mathrm{dd}, J=10.3,6.1,1 \mathrm{H})$, $3.31(\mathrm{~s}, 3 \mathrm{H}), 2.31(\mathrm{~m}, 1 \mathrm{H}), 2.16(\mathrm{~m}, 1 \mathrm{H}), 1.96(\mathrm{ddd}, J=12.4,11.7,10.4,1 \mathrm{H}), 1.43(\mathrm{~s}, 3 \mathrm{H}), 1.08(\mathrm{~d}, J=6.7,3 \mathrm{H})$; ${ }^{13} \mathrm{C}$ NMR $\left(100 \mathrm{MHz}, \mathrm{CDCl}_{3}\right) \delta 143.4,128.5,127.5,126.9,107.5,81.0,48.9,45.7,41.4,20.1,12.9$.

Minor diastereomer of 15. ${ }^{1} \mathrm{H}$ NMR $\left(400 \mathrm{MHz} \mathrm{CDCl}_{3}\right) \delta 7.25-7.35(5 \mathrm{H}), 4.94(\mathrm{dd}, J=8.7,6.9,1 \mathrm{H}), 3.31(\mathrm{~s}$, $3 \mathrm{H}), 2.61$ (ddd, $J=12.3,7.7,6.8,1 \mathrm{H}), 2.37$ (sextet, $J=7.2,1 \mathrm{H}), 1.47$ (ddd, $J=12.3,8.7,7.1,1 \mathrm{H}), 1.41(\mathrm{~s}, 3 \mathrm{H}$ ), $1.04(\mathrm{~d}, J=7.2,3 \mathrm{H}) ;{ }^{13} \mathrm{C} \mathrm{NMR}\left(100 \mathrm{MHz}, \mathrm{CDCl}_{3}\right) \delta 142.4,128.6,127.5,126.1,109.9,78.5,48.8,43.1,18.6$, 17.5 .
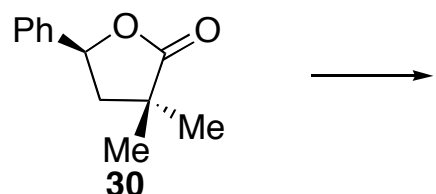

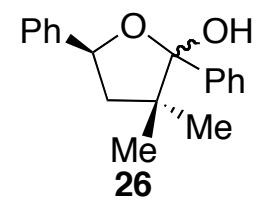


2,2-Dimethyl-1,4-diphenyltetrahydrofuran-1-ol (26). ${ }^{5}$ Cerium chloride $\left(\mathrm{CeCl}_{3} \cdot 7 \mathrm{H}_{2} \mathrm{O}\right)(24.5 \mathrm{~g}, 65.8$ mmol), ground to a fine powder, was heated to $140{ }^{\circ} \mathrm{C}$ with evacuation (133 Pa). After $1 \mathrm{~h}$, the cerium chloride was cooled to $22^{\circ} \mathrm{C}$ and placed under an atmosphere of nitrogen. A solution of lactone $30^{4}(5.00 \mathrm{~g}, 26.3 \mathrm{mmol})$ in $150 \mathrm{~mL}$ of THF was added and the mixture was stirred for $1 \mathrm{~h}$ at $22^{\circ} \mathrm{C}$. The reaction mixture was cooled to $-45^{\circ} \mathrm{C}$ and phenylmagnesium bromide $\left(63 \mathrm{~mL}, 63 \mathrm{mmol}, 1.0 \mathrm{M}\right.$ in THF) was added. After $1 \mathrm{~h}$ at $-45^{\circ} \mathrm{C}$, the reaction mixture was treated with $100 \mathrm{~mL}$ of $\mathrm{H}_{2} \mathrm{O}$ and warmed to $22{ }^{\circ} \mathrm{C}$. The reaction mixture was filtered through a pad of Celite and extracted with $3 \times 50 \mathrm{~mL}$ of $\mathrm{Et}_{2} \mathrm{O}$. The combined organic phases were dried $\left(\mathrm{Na}_{2} \mathrm{SO}_{4}\right)$ and concentrated in vacuo to provide a 1:1 mixture of hemiketal 26 and starting lactone 30 . ${ }^{1} \mathrm{H} \mathrm{NMR}$ spectroscopic analysis of the unpurified product showed the hemiketal as a pair of diastereomers in a ratio of 75:25. Purification by flash chromatography (2:98 - 20:80 EtOAc/hexanes) provided a diastereomeric mixture of 26 as a white solid (3.05 g, 43\%). Elemental analysis, HRMS, melting point, and IR data were obtained for 26 as a mixture of diastereomers: IR (KBr) 3546, 2934, 1492, $1056 \mathrm{~cm}^{-1}$; mp 119-120 ${ }^{\circ} \mathrm{C}$; HRMS (CI/isobutane) $m / z$ calcd for $\mathrm{C}_{18} \mathrm{H}_{19} \mathrm{O}_{2}(\mathrm{M}-\mathrm{H})^{+}$267.1385, found 267.1390. Anal. Calcd for $\mathrm{C}_{18} \mathrm{H}_{20} \mathrm{O}_{2}$ : $\mathrm{C}$, 80.56; H, 7.51. Found: C, 80.53; H, 7.35.

Major diastereomer of 26. ${ }^{1} \mathrm{H} \mathrm{NMR}\left(500 \mathrm{MHz}, \mathrm{CDCl}_{3}\right) \delta 7.29-7.74(\mathrm{~m}, 10 \mathrm{H}), 5.37(\mathrm{dd}, J=10.5,6.4,1 \mathrm{H})$, $2.69(\mathrm{~s}, 1 \mathrm{H}), 2.43(\mathrm{t}, J=10.8,1 \mathrm{H}), 2.24(\mathrm{dd}, J=12.0,6.4,1 \mathrm{H}), 1.27(\mathrm{~s}, 3 \mathrm{H}), 0.80(\mathrm{~s}, 3 \mathrm{H}) ;{ }^{13} \mathrm{C} \mathrm{NMR}(125 \mathrm{MHz}$, $\left.\mathrm{CDCl}_{3}\right) \delta 143.8,141.5,128.6,128.3,127.9,127.6,127.0,126.7,108.4,80.1,48.7,47.5,25.1,21.9$.

Minor diastereomer of 26. ${ }^{1} \mathrm{H}$ NMR $\left(500 \mathrm{MHz}^{\mathrm{CDCl}} \mathrm{CDC}_{3}\right.$, distinctive peaks) $\delta 5.45(\mathrm{dd}, J=9.9,4.6,1 \mathrm{H}) 2.78$ $(\mathrm{dd}, J=12.4,10.0,1 \mathrm{H}), 2.50(\mathrm{~s}, 1 \mathrm{H}), 1.96(\mathrm{dd}, J=12.0,4.8,1 \mathrm{H}) 1.28(\mathrm{~s}, 3 \mathrm{H}), 0.65(\mathrm{~s}, 3 \mathrm{H})$.

\section{Nucleophilic substitution of acetate substrates}

General Procedure for Allylation of $\boldsymbol{\gamma}$-Lactol Acetates. A solution of acetate in $\mathrm{CH}_{2} \mathrm{Cl}_{2}(0.10 \mathrm{M})$ was treated with allyltrimethylsilane (4 equiv) and then cooled to $-78{ }^{\circ} \mathrm{C}$. After treatment with Lewis acid (1.1 equiv), the reaction mixture was warmed to $22{ }^{\circ} \mathrm{C}$ over $2 \mathrm{~h}$. The reaction mixture was treated with saturated aqueous $\mathrm{Na}_{2} \mathrm{HPO}_{4}\left(1 \mathrm{~mL}\right.$ per mmol of acetate). The aqueous layer was then extracted three times with $\mathrm{CH}_{2} \mathrm{Cl}_{2}$ (1 $\mathrm{mL}$ per mmol of acetate), and the organic phases were dried $\left(\mathrm{Na}_{2} \mathrm{SO}_{4}\right)$ and concentrated in vacuo.
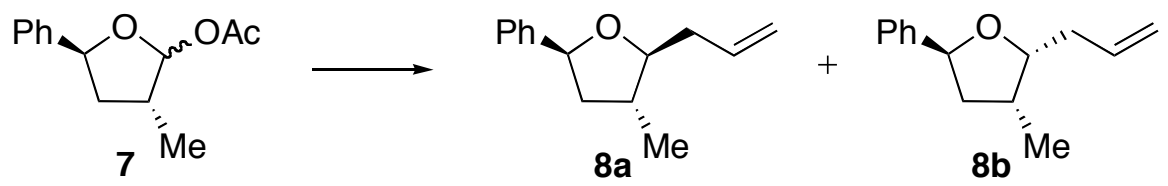

1-Allyl-2-methyl-4-phenyltetrahydrofuran (8). The standard allylation procedure was followed with acetate $7(0.52 \mathrm{~g}, 0.24 \mathrm{mmol})$ and $\mathrm{BF}_{3} \cdot \mathrm{OEt}_{2}(0.036 \mathrm{~mL}, 0.29 \mathrm{mmol})$. GC and ${ }^{1} \mathrm{H} \mathrm{NMR}$ spectroscopic analysis of the unpurified product showed a 72:28 ratio of 1,4-cis:trans diastereomers. Purification by flash chromatography (0:100 - 2:98 EtOAc/hexanes) provided the product as a colorless oil $(0.039 \mathrm{~g}, 81 \%)$. The purified product was characterized as a mixture of diastereomers: ${ }^{1} \mathrm{H}$ NMR $\left(500 \mathrm{MHz}, \mathrm{CDCl}_{3}\right) \delta 7.23-7.37(\mathrm{~m}, 8 \mathrm{H}), 5.98(\mathrm{~m}, 1.6 \mathrm{H})$, $5.16(\mathrm{~m}, 3.8 \mathrm{H}), 4.98(\mathrm{~m}, 1 \mathrm{H}), 4.23(\mathrm{~m}, 0.6 \mathrm{H}), 3.63(\mathrm{dd}, J=11.7,6.5,1 \mathrm{H}), 2.45(\mathrm{~m}, 3.7 \mathrm{H}), 2.12(\mathrm{~m}, 0.6 \mathrm{H}), 2.07$ $(\mathrm{m}, 0.6 \mathrm{H}), 2.02(\mathrm{~m}, 3.8 \mathrm{H}), 1.08(\mathrm{~m}, 3 \mathrm{H}), 1.04(\mathrm{~m}, 1.8 \mathrm{H}) ;{ }^{13} \mathrm{C} \mathrm{NMR}\left(125 \mathrm{MHz}, \mathrm{CDCl}_{3}\right) \delta$ 145.1, 144.1, 135.7, $135.5,128.5,128.4,127.2,127.1,125.9,125.6,117.0,116.7,86.2,82.2,79.5,78.7,43.4,43.3,39.1,37.9,36.4$, 35.6, 17.8, 14.1; IR (thin film) 3032, 2964, 1639, 1453, $1088 \mathrm{~cm}^{-1}$; HRMS (GC-MS, EI) $m / z$ calcd for $\mathrm{C}_{14} \mathrm{H}_{18} \mathrm{O}$ $\left(\mathrm{M}^{+}\right)$202.1358, found 202.1359. 


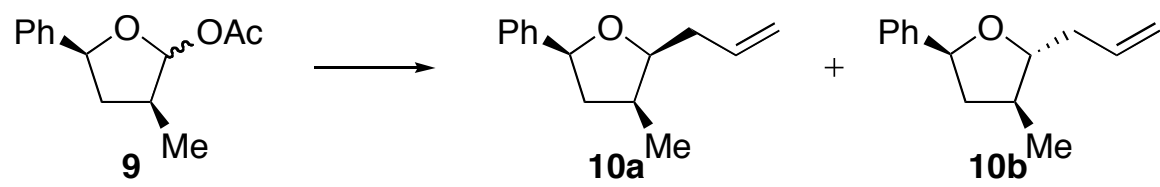

1-Allyl-2-methyl-4-phenyltetrahydrofuran (10). The standard allylation procedure was followed with acetate $9(0.150 \mathrm{~g}, 0.681 \mathrm{mmol})$ and $\mathrm{SnBr}_{4}\left(0.82 \mathrm{~mL}, 0.82 \mathrm{mmol}, 1.0 \mathrm{M}\right.$ in $\left.\mathrm{CH}_{2} \mathrm{Cl}_{2}\right)$. GC and ${ }^{1} \mathrm{H}$ NMR spectroscopic analysis of the unpurified product showed a 51:49 ratio of 1,4-cis:trans diastereomers. Purification by flash chromatography $(0: 100-2: 98 \mathrm{EtOAc} /$ hexanes $)$ provided the product as a pure sample of $\mathbf{1 0 b}(0.010 \mathrm{~g}, 7 \%)$ and a mixture of 10a and 10b $(0.112 \mathrm{~g}, 81 \%)$. Elemental analysis, HRMS, and IR data were obtained for 10 as a mixture of diastereomers: IR (thin film) 3073, 2961, 1641, 1451, $912 \mathrm{~cm}^{-1}$; HRMS (GC-MS, EI) $\mathrm{m} / \mathrm{z}$ calcd for $\mathrm{C}_{14} \mathrm{H}_{18} \mathrm{O}\left(\mathrm{M}^{+}\right)$202.1358, found 202.1361. Anal. Calcd for $\mathrm{C}_{14} \mathrm{H}_{18} \mathrm{O}: \mathrm{C}, 83.12 ; \mathrm{H}, 8.97$. Found: $\mathrm{C}, 82.91 ; \mathrm{H}$, 8.86 .

1,4-trans diastereomer 10b. ${ }^{1} \mathrm{H} \mathrm{NMR}\left(500 \mathrm{MHz}, \mathrm{CDCl}_{3}\right) \delta 7.21-7.35(\mathrm{~m}, 5 \mathrm{H}), 5.96$ (ddt, $J=17.2,10.2,6.9$, $1 \mathrm{H}), 5.16(\mathrm{~m}, 1 \mathrm{H}), 5.14(\mathrm{~m}, 1 \mathrm{H}), 4.97(\mathrm{dd}, J=10.0,5.9,1 \mathrm{H}), 3.76(\mathrm{~m}, 1 \mathrm{H}), 2.46(\mathrm{~m}, 2 \mathrm{H}), 2.37(\mathrm{~m}, 1 \mathrm{H}), 2.12$ $(\mathrm{m}, 1 \mathrm{H}), 1.58(\mathrm{~m}, 1 \mathrm{H}), 1.07(\mathrm{~d}, J=6.5,3 \mathrm{H}) ;{ }^{13} \mathrm{C} \mathrm{NMR}\left(125 \mathrm{MHz}, \mathrm{CDCl}_{3}\right) \delta 144.1,135.4,128.5,127.3,125.8$, $117.0,85.7,80.2,45.1,40.1,38.8,16.8$.

1,4-cis diastereomer 10a. ${ }^{1} \mathrm{H} \mathrm{NMR}\left(500 \mathrm{MHz}, \mathrm{CDCl}_{3}\right.$, distinctive peaks) $\delta 4.87(\mathrm{dd}, J=8.9,6.5,1 \mathrm{H}), 4.08(\mathrm{~m}$, $1 \mathrm{H}), 1.53(\mathrm{~m}, 1 \mathrm{H}), 1.03(\mathrm{~d}, J=6.8,3 \mathrm{H}) ;{ }^{13} \mathrm{C} \mathrm{NMR}\left(125 \mathrm{MHz}, \mathrm{CDCl}_{3}\right.$, distinctive peaks) $\delta 143.6,136.1,128.4$, $127.2,126.0,116.7,81.7,80.3,43.2,36.6,36.1,15.4$.
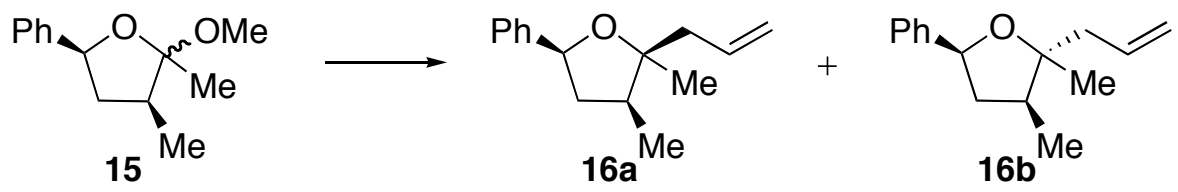

1-Allyl-1,2-dimethyl-4-phenyltetrahydrofuran (16). The standard allylation procedure was followed with methyl acetal 15 (0.024 g, $0.12 \mathrm{mmol})$ and $\mathrm{SnBr}_{4}\left(0.14 \mathrm{~mL}, 0.14 \mathrm{mmol}, 1.0 \mathrm{M}\right.$ in $\left.\mathrm{CH}_{2} \mathrm{Cl}_{2}\right)$. GC and ${ }^{1} \mathrm{H} \mathrm{NMR}$ spectroscopic analysis of the unpurified product showed a 66:34 ratio of 1,4-cis:trans diastereomers. Purification by flash chromatography (0:100 - 2:98 EtOAc/hexanes) provided the product as a mixture of 16a and $16 \mathrm{~b}(0.023 \mathrm{~g}, 88 \%)$. The purified product was characterized as a mixture of diastereomers: ${ }^{1} \mathrm{H}$ NMR (500 $\left.\mathrm{MHz}, \mathrm{CDCl}_{3}\right) \delta$ 7.27-7.42 (m, 8H), 6.13 (dddd, $\left.J=17.1,10.4,8.4,5.9,1 \mathrm{H}\right), 6.00(\mathrm{~m}, 0.6 \mathrm{H}), 5.18(\mathrm{~m}, 3.2 \mathrm{H})$, $5.02(\mathrm{dd}, J=10.4,5.5,1 \mathrm{H}), 4.92(\mathrm{dd}, J=10.7,5.1,0.6 \mathrm{H}), 2.30-2.50(\mathrm{~m}, 5.4 \mathrm{H}), 2.16(\mathrm{dd}, J=13.8,8.2,1 \mathrm{H})$, $1.70(\mathrm{~m}, 1.6 \mathrm{H}), 1.31(\mathrm{~s}, 3 \mathrm{H}), 1.23(\mathrm{~s}, 1.8 \mathrm{H}), 1.10(\mathrm{~d}, J=6.9,3 \mathrm{H}), 1.04(\mathrm{~d}, J=6.5,1.8 \mathrm{H}) ;{ }^{13} \mathrm{C} \mathrm{NMR}(125 \mathrm{MHz}$, $\left.\mathrm{CDCl}_{3}\right) \delta 144.0,135.7,135.3,128.74,128.69,127.6,127.5,126.24,126.20,118.0,117.9,84.7,84.4,79.8,79.6$, 46.2, 45.5, 44.5, 44.0, 42.1, 41.8, 25.7, 23.5, 14.9, 14.5; IR (thin film) 3070, 2956, 1633, 1446, $1031 \mathrm{~cm}^{-1}$; HRMS (GC-MS, EI) $m / z$ calcd for $\mathrm{C}_{14} \mathrm{H}_{17} \mathrm{O}\left(\mathrm{M}-\mathrm{CH}_{3}\right)^{+}$201.1279, found 201.1272. Anal. Calcd for $\mathrm{C}_{15} \mathrm{H}_{20} \mathrm{O}$ : C, 83.28; H, 9.32. Found: C, 83.06; H, 9.56.
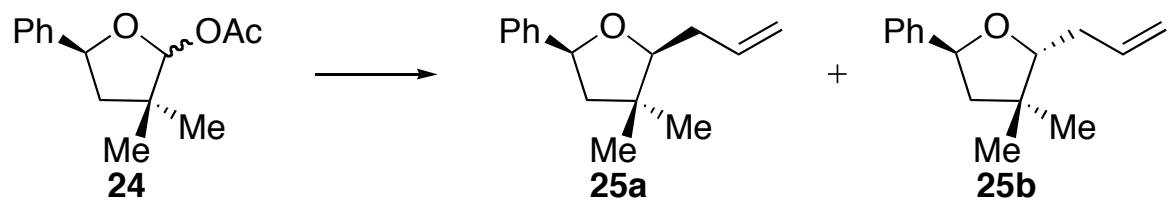

1-Allyl-2,2-dimethyl-4-phenyltetrahydrofuran (25). The standard allylation procedure was followed with acetate $24(0.18 \mathrm{~g}, 0.77 \mathrm{mmol})$ and $\mathrm{SnBr}_{4}\left(0.92 \mathrm{~mL}, 0.92 \mathrm{mmol}, 1.0 \mathrm{M}\right.$ in $\left.\mathrm{CH}_{2} \mathrm{Cl}_{2}\right)$. GC analysis of the unpurified product showed one peak. ${ }^{1} \mathrm{H}$ NMR spectroscopic analysis resolved key peaks to show a 90:10 
mixture of 1,4-cis:trans diastereomers. ${ }^{6}$ Purification by flash chromatography (0:100 - 2:98 EtOAc/hexanes) provided the product as a pure sample of 1,4-cis isomer $25 \mathbf{a}(0.008 \mathrm{~g})$ and a mixture of 1,4-cis and trans isomers 25a and 25b $(0.145 \mathrm{~g}, 87 \%)$. HRMS and IR data were obtained for $\mathbf{2 5}$ as a mixture of diastereomers: IR (thin film) 3072, 2952, 1638, 1453, $905 \mathrm{~cm}^{-1}$; HRMS (GC-MS, EI) $m / z$ calcd for $\mathrm{C}_{15} \mathrm{H}_{19} \mathrm{O}(\mathrm{M}-\mathrm{H})^{+} 215.1436$, found 215.1438 .

1,4-cis diastereomer 25a. ${ }^{1} \mathrm{H}$ NMR $\left(500 \mathrm{MHz}, \mathrm{C}_{6} \mathrm{D}_{6}\right) \delta$ 7.09-7.40 (m, 5H), $6.10(\mathrm{~m}, 1 \mathrm{H}), 5.15(\mathrm{~m}, 1 \mathrm{H}), 5.08$ $(\mathrm{m}, 1 \mathrm{H}), 4.80(\mathrm{t}, J=7.9,1 \mathrm{H}), 3.50(\mathrm{dd}, J=9.5,3.7,1 \mathrm{H}), 2.33(\mathrm{~m}, 1 \mathrm{H}), 2.10(\mathrm{~m}, 1 \mathrm{H}), 1.83(\mathrm{dd}, J=12.4,8.2$, $1 \mathrm{H}), 1.51(\mathrm{dd}, J=12.4,7.7,1 \mathrm{H}), 0.84(\mathrm{~s}, 3 \mathrm{H}), 0.77(\mathrm{~s}, 3 \mathrm{H}) ;{ }^{13} \mathrm{C} \mathrm{NMR}\left(125 \mathrm{MHz}, \mathrm{CDCl}_{3}\right) \delta 143.9,136.5,128.5$, $127.1,125.9,116.5,87.8,78.7,50.2,41.5,35.9,27.3,24.1$.

1,4-trans diastereomer 25b. ${ }^{1} \mathrm{H}$ NMR $\left(500 \mathrm{MHz}, \mathrm{CDCl}_{3}\right.$, distinctive peaks) $\delta 4.99(\mathrm{dd}, J=9.8,6.9,1 \mathrm{H}), 3.68$ $(\mathrm{dd}, J=9.2,3.8,1 \mathrm{H}) ;{ }^{13} \mathrm{C} \mathrm{NMR}\left(125 \mathrm{MHz}, \mathrm{CDCl}_{3}\right.$, distinctive peaks) $\delta 136.4,128.4,127.06,125.5,116.3,87.1$, 78.2, 51.6, 34.9, 25.1, 21.4.

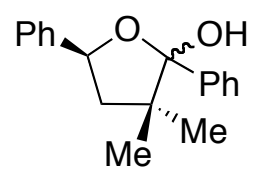

26

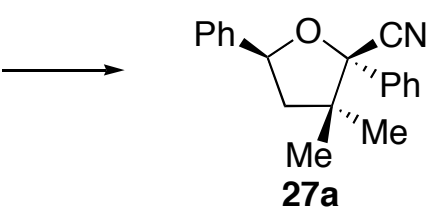

27a

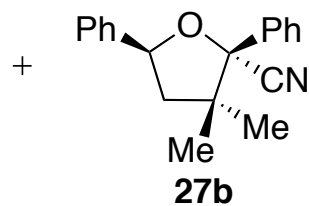

27b

1-Cyano-2,2-dimethyl-1,4-diphenyltetrahydrofuran (27). To a solution of lactol 26 (0.050 g, $0.20 \mathrm{mmol})$ in $2 \mathrm{~mL}$ of $\mathrm{CH}_{2} \mathrm{Cl}_{2}$ was added $\mathrm{Me}_{3} \mathrm{SiCN}(0.080 \mathrm{~mL}, 0.57 \mathrm{mmol})$. The reaction mixture was cooled to $-78^{\circ} \mathrm{C}$ and $\mathrm{Me}_{3} \operatorname{SiOTf}(0.070 \mathrm{~mL}, 0.40 \mathrm{mmol})$ was added. After $2 \mathrm{~h}$ at $-78{ }^{\circ} \mathrm{C}$, the reaction mixture was treated with $2 \mathrm{~mL}$ of a cooled $\left(-78{ }^{\circ} \mathrm{C}\right)$ 1:1:1 mixture of $\mathrm{Et}_{3} \mathrm{~N}, \mathrm{MeOH}$, and $\mathrm{CH}_{2} \mathrm{Cl}_{2}$. The reaction mixture was washed with saturated aqueous $\mathrm{NaHCO}_{3}(5 \mathrm{~mL})$ and extracted with $\mathrm{Et}_{2} \mathrm{O}(3 \times 5 \mathrm{~mL})$. The organic phases were washed with brine $(5 \mathrm{~mL})$, dried $\left(\mathrm{Na}_{2} \mathrm{SO}_{4}\right)$, and concentrated in vacuo. $\mathrm{GC}$ and ${ }^{1} \mathrm{H} \mathrm{NMR}$ spectroscopic analysis of the unpurified product showed a pair of diastereomers in a 96:4 ratio. Purification of the residue by flash chromatography (0:100 - 5:95 EtOAc/hexanes) yielded 27 (0.045 g, 86\%). Elemental analysis, HRMS, and IR data were obtained for 27 as a mixture of diastereomers: IR (thin film) 3066, 2967, 2244, 1600, $1494 \mathrm{~cm}^{-1}$; HRMS (CI/isobutane) $m / z$ calcd for $\mathrm{C}_{19} \mathrm{H}_{19} \mathrm{NO}\left(\mathrm{M}^{+}\right)$277.1466, found 277.1472. Anal. Calcd for $\mathrm{C}_{19} \mathrm{H}_{19} \mathrm{NO} \mathrm{C}$, 82.28; H, 6.90; N, 5.05. Found: C, 82.20; H, 7.02; N, 4.86 .

1,4-cis diastereomer 27a. ${ }^{1} \mathrm{H} \mathrm{NMR}\left(500 \mathrm{MHz}, \mathrm{CDCl}_{3}\right) \delta 7.25-7.58(\mathrm{~m}, 10 \mathrm{H}), 5.41(\mathrm{dd}, J=10.1,6.7,1 \mathrm{H}), 2.38$ $(\mathrm{m}, 2 \mathrm{H}), 1.44(\mathrm{~s}, 3 \mathrm{H}), 0.75(\mathrm{~s}, 3 \mathrm{H}) ;{ }^{13} \mathrm{C} \mathrm{NMR}\left(125 \mathrm{MHz}, \mathrm{CDCl}_{3}\right) \delta 141.5,135.8,129.1,128.9,128.51,128.1$, 126.2, 125.7, 121.2, 88.2, 81.6, 49.9, 48.5, 23.6, 22.8.

1,4-trans diastereomer 27b. ${ }^{1} \mathrm{H}$ NMR $\left(500 \mathrm{MHz}, \mathrm{CDCl}_{3}\right.$, distinctive peaks) $\delta 5.48(\mathrm{dd}, J=9.5,5.8,1 \mathrm{H}), 2.69$ (dd, $J=12.9,9.7,1 \mathrm{H}), 2.06(\mathrm{dd}, J=12.9,5.9,1 \mathrm{H}), 0.63(\mathrm{~s}, 3 \mathrm{H}) ;{ }^{13} \mathrm{C} \mathrm{NMR}\left(125 \mathrm{MHz}, \mathrm{CDCl}_{3}\right.$, distinctive peaks) ठ $128.8,128.54,127.8,125.9,125.8,78.4,47.6,47.4,25.6,24.8$.

\section{Control Experiments for $\mathrm{Me}_{3} \mathrm{SiCN}$ Addition:}

The addition of $\mathrm{Me}_{3} \mathrm{SiCN}$ to lactol 26 at $-78{ }^{\circ} \mathrm{C}$ proceeds irreversibly: The procedure for $\mathrm{Me}_{3} \mathrm{SiCN}$ addition was followed with a 55:45 mixture of the 1,4-trans and 1,4-cis nitrile isomers $27 \mathbf{b}$ and 27a. GC analysis of the unpurified product showed an unaffected 55:45 ratio of 1,4-trans and 1,4-cis isomers.

\section{Control Experiments for Allylation of $\gamma$-Acetals:}

The diastereoselectivity of nucleophilic substitution is independent of the anomer ratio of the starting acetal: The standard allylation procedure was followed with a 99:1 anomer ratio of acetal $15(0.011 \mathrm{~g}, 0.053 \mathrm{mmol})$ and $\mathrm{SnBr}_{4}\left(0.064 \mathrm{~mL}, 0.064 \mathrm{mmol}, 1.0 \mathrm{M}\right.$ in $\left.\mathrm{CH}_{2} \mathrm{Cl}_{2}\right)$. $\mathrm{GC}$ analysis of the unpurified product showed that 
allylated product 16 was formed as a 70:30 mixture of diastereomers. Allylation of a 20:80 anomer ratio of acetal 15 also led to allylated product 16 as a 70:30 mixture of diastereomers as determined by GC analysis.

\section{Stereochemical proofs of nucleophilic substituted products}

A. The stereochemistry of $\mathbf{8}$ was determined by analysis of nOe data:

Relevant DPFGSE-nOe data (mixing time $2.0 \mathrm{~s}$ ): (the peaks in the ${ }^{1} \mathrm{H}$ NMR spectra were assigned using ${ }^{1} \mathrm{H} /{ }^{1} \mathrm{H}$ COSY, ${ }^{1} \mathrm{H}$ NMR chemical shifts, and ${ }^{1} \mathrm{H}$ NMR coupling constants)

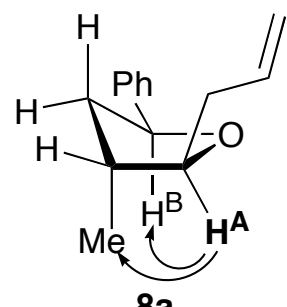

$8 \mathbf{a}$

$\left(1 S^{*}, 2 R^{*}, 4 S^{*}\right)$-1-Allyl-2-methyl-4-phenyltetrahydrofuran (1,4-cis, major)

nOe experiments were performed for 8a using a 64:36 mixture of $\mathbf{8 a}$ and $\mathbf{8 b}$

$\mathbf{H}^{\mathrm{A}}$ irradiated: $\mathrm{H}^{\mathrm{B}}(1.5 \%)$, Me $(2.2 \%)$

$\mathbf{H}^{\mathrm{B}}$ irradiated: $\mathrm{H}^{\mathrm{A}}(2.2 \%)$

Note: The observation of nOe between $\mathrm{H}^{\mathrm{B}}$ and $\mathrm{H}^{\mathrm{A}}$ suggests a 1,4-cis configuration.

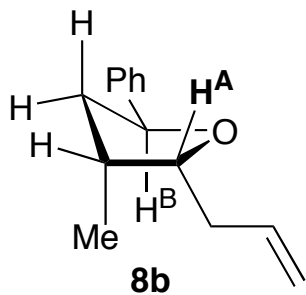

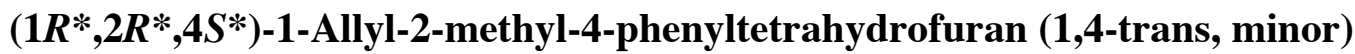

nOe experiments were performed for $\mathbf{8 b}$ using a 64:36 mixture of $\mathbf{8 a}$ and $\mathbf{8 b}$

Note: The absence of nOe between $\mathrm{H}^{\mathrm{A}}$ and $\mathrm{H}^{\mathrm{B}}$ suggests a 1,4-trans configuration.

B. The stereochemistry of $\mathbf{1 0}$ was determined by analysis of nOe data:

Relevant DPFGSE-nOe data (mixing time $2.0 \mathrm{~s}$ ): (the peaks in the ${ }^{1} \mathrm{H}$ NMR spectra were assigned using ${ }^{1} \mathrm{H} /{ }^{1} \mathrm{H}$ COSY, ${ }^{1} \mathrm{H}$ NMR chemical shifts, and ${ }^{1} \mathrm{H}$ NMR coupling constants) 


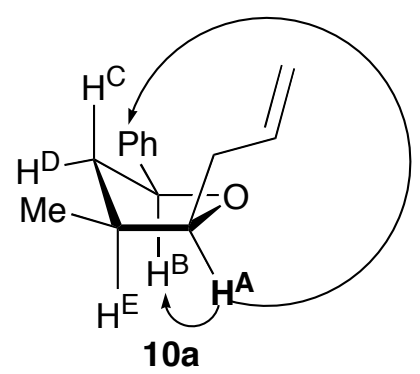

$\left(1 S^{*}, 2 S^{*}, 4 S^{*}\right)$-1-Allyl-2-methyl-4-phenyltetrahydrofuran (1,4-cis, major) nOe experiments were performed for 10a using a 56:44 mixture of 10a and $\mathbf{1 0 b}$ $\mathbf{H}^{\mathrm{A}}$ irradiated: $\mathrm{H}^{\mathrm{B}}(2.8 \%), \mathrm{Ph}(1.0 \%)$

Note: The observation of nOe between $\mathrm{H}^{\mathrm{A}}$ and $\mathrm{H}^{\mathrm{B}}$ suggests a 1,4-cis configuration.

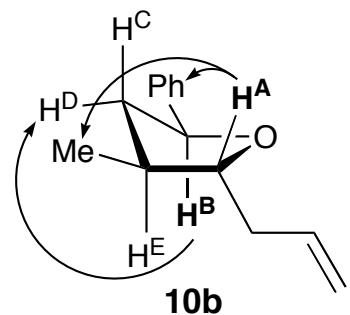

$\left(1 R^{*}, 2 S^{*}, 4 S^{*}\right)$-1-Allyl-2-methyl-4-phenyltetrahydrofuran (1,4-trans, minor) nOe experiments were performed for $\mathbf{1 0 b}$ using a pure sample of the isomer $\mathbf{H}^{\mathbf{A}}$ irradiated: $\mathrm{Ph}(1.9 \%), \mathrm{Me}(3.0 \%)$

$\mathbf{H}^{\mathbf{B}}$ irradiated: $\mathrm{H}^{\mathrm{D}}(3.8 \%)$

Note: The absence of nOe between $\mathrm{H}^{\mathrm{A}}$ and $\mathrm{H}^{\mathrm{B}}$ suggests a 1,4-trans configuration.

C. The stereochemistry of $\mathbf{1 6}$ was determined by analysis of nOe data:

Relevant DPFGSE-nOe data (mixing time $2.0 \mathrm{~s}$ ): (the peaks in the ${ }^{1} \mathrm{H}$ NMR spectra were assigned using ${ }^{1} \mathrm{H} /{ }^{1} \mathrm{H}$ COSY, ${ }^{1} \mathrm{H}$ NMR chemical shifts, and ${ }^{1} \mathrm{H}$ NMR coupling constants)

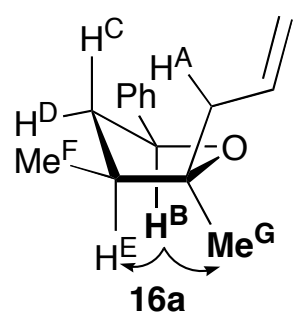

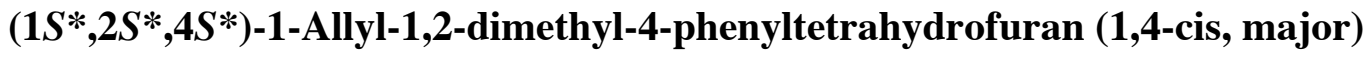

nOe experiments were performed for 16a using a 64:36 mixture of 16a and 16b $\mathbf{H}^{\mathbf{B}}$ irradiated: $\mathrm{H}^{\mathrm{E}}(2.6 \%), \mathrm{Me}^{\mathrm{G}}(0.8 \%)$

$\mathbf{M e}^{\mathrm{G}}$ irradiated: $\mathrm{H}^{\mathrm{B}}(0.8 \%), \mathrm{H}^{\mathrm{E}}(3.3 \%), \mathrm{Me}^{\mathrm{F}}(0.7 \%)$

Note: The observation of nOe between $\mathrm{H}^{\mathrm{B}}$ and $\mathrm{Me}^{\mathrm{G}}$ and the absence of nOe between $\mathrm{H}^{\mathrm{A}}$ and $\mathrm{H}^{\mathrm{B}}$ suggests a 1,4-cis configuration. 


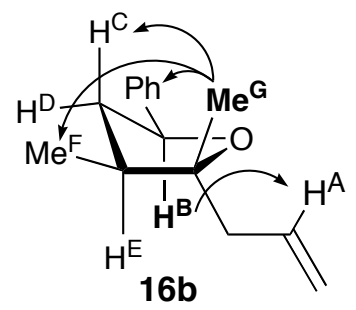

$\left(1 R^{*}, 2 S^{*}, 4 S^{*}\right)$-1-Allyl-1,2-dimethyl-4-phenyltetrahydrofuran (1,4-trans)

nOe experiments were performed for $\mathbf{1 6 b}$ using a 64:36 mixture of $\mathbf{1 6 a}$ and $\mathbf{1 6} \mathbf{b}$ $\mathbf{H}^{\mathbf{B}}$ irradiated: $\mathrm{H}^{\mathrm{A}}(0.8 \%)$

$\mathbf{M e}^{\mathrm{G}}$ irradiated: $\mathrm{H}^{\mathrm{C}}(1.8 \%), \mathrm{Ph}(1.9 \%), \mathrm{Me}^{\mathrm{F}}(2.8 \%)$

Note: The absence of nOe between $\mathrm{H}^{\mathrm{B}}$ and $\mathrm{Me}^{\mathrm{G}}$ suggests a 1,4-cis configuration.

D. The stereochemistry of $\mathbf{2 5}$ was determined by analysis of nOe data:

Relevant DPFGSE-nOe data (mixing time 2.0 s): (the peaks in the ${ }^{1} \mathrm{H}$ NMR spectra were assigned using ${ }^{1} \mathrm{H} /{ }^{1} \mathrm{H}$ COSY, ${ }^{1} \mathrm{H}$ NMR chemical shifts, and ${ }^{1} \mathrm{H}$ NMR coupling constants)

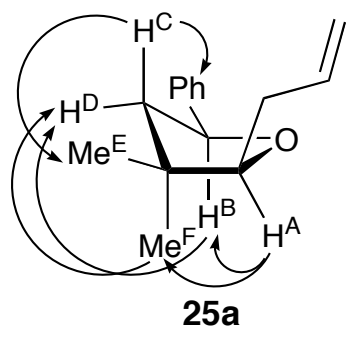

$\left(1 S^{*}, 4 S^{*}\right)$-1-Allyl-2,2-dimethyl-4-phenyltetrahydrofuran (1,4-cis, major)

nOe experiments were performed for 25a using a pure sample of the isomer

$\mathbf{H}^{\mathrm{A}}$ irradiated: $\mathrm{H}^{\mathrm{B}}(2.6 \%), \mathrm{Me}^{\mathrm{F}}(2.8 \%)$

$\mathbf{H}^{\mathrm{B}}$ irradiated: $\mathrm{H}^{\mathrm{A}}(2.2 \%), \mathrm{H}^{\mathrm{D}}(2.5 \%), \mathrm{Me}^{\mathrm{F}}(0.6 \%)$

$\mathbf{H}^{\mathrm{C}}$ irradiated: $\mathrm{Ph}(1.3 \%), \mathrm{Me}^{\mathrm{E}}(2.3 \%)$

Me ${ }^{\mathrm{F}}$ irradiated: $\mathrm{H}^{\mathrm{A}}(1.9 \%), \mathrm{H}^{\mathrm{B}}(0.6 \%), \mathrm{H}^{\mathrm{D}}(1.7 \%)$

Note: The observation of nOe between $\mathrm{H}^{\mathrm{B}}$ and $\mathrm{H}^{\mathrm{A}}$ suggests a 1,4-cis configuration.

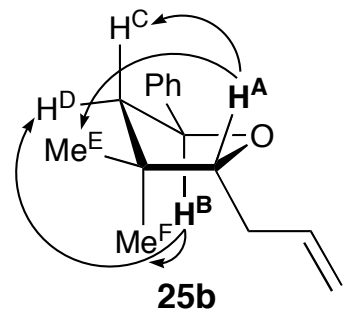

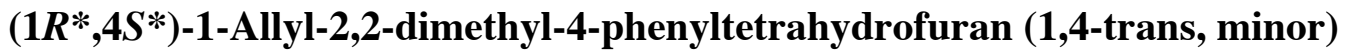
nOe experiments were performed for $\mathbf{2 5} \mathbf{b}$ using a 17:83 mixture of $\mathbf{2 5} \mathbf{a}$ and $\mathbf{2 5} \mathbf{b}$ in $\mathrm{C}_{6} \mathrm{D}_{6}$ $\mathbf{H}^{\mathrm{A}}$ irradiated: $\mathrm{H}^{\mathrm{C}}(1.9 \%), \mathrm{Me}^{\mathrm{E}}(3.1 \%)$

$\mathbf{H}^{\mathbf{B}}$ irradiated: $\mathrm{H}^{\mathrm{D}}(2.5 \%), \mathrm{Me}^{\mathrm{F}}(2.9 \%)$ 
Note: The absence of nOe between $\mathrm{H}^{\mathrm{A}}$ and $\mathrm{H}^{\mathrm{B}}$ suggests a 1,4-trans configuration.

E. The stereochemistry of nitrile $\mathbf{2 7}$ was determined by conversion to amine $\mathbf{3 2}$ and subsequent analysis of nOe data of 32:
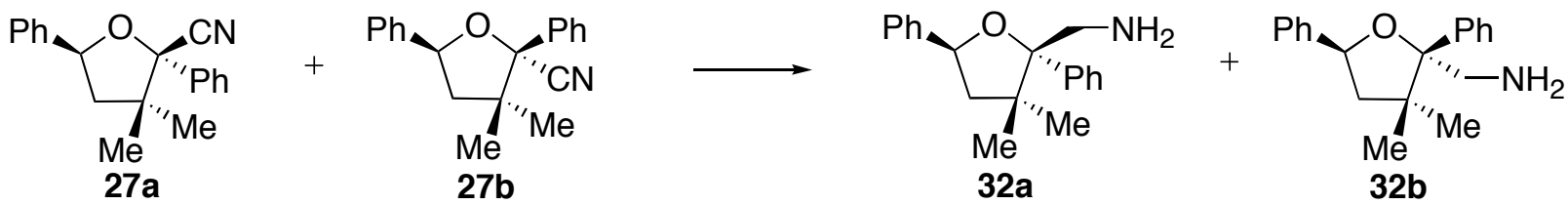

(2,2-Dimethyl-1,4-diphenyltetrahydrofuran-1-yl)methylamine (32). To a cooled $\left(0{ }^{\circ} \mathrm{C}\right)$ solution of $\mathrm{AlH}_{3}\left(2.4 \mathrm{~mL}, 1.4 \mathrm{mmol}, 0.60 \mathrm{M}\right.$ in THF) was added nitrile $27(0.10 \mathrm{~g}, 0.36 \mathrm{mmol})$ in $10 \mathrm{~mL}$ of THF. ${ }^{7}$ After $36 \mathrm{~h}$ at $22{ }^{\circ} \mathrm{C}$, the reaction mixture was treated with $43 \mu \mathrm{L}$ of $\mathrm{H}_{2} \mathrm{O}, 50 \mu \mathrm{L}$ of $15 \% \mathrm{NaOH}, 0.10 \mathrm{~mL}$ of $\mathrm{H}_{2} \mathrm{O}$, and $15 \mathrm{mg}$ of $\mathrm{Na}_{2} \mathrm{SO}_{4}$. The mixture was filtered through filter paper and concentrated in vacuo to provide the product as an oil. Purification of this residue by flash chromatography (20:80 - 80:20 EtOAc/hexanes) afforded $32(0.062 \mathrm{~g}, 61 \%)$. The two diastereomers were separable in small amounts with careful chromatography. Elemental analysis, HRMS, and IR data were obtained for $\mathbf{3 2}$ as a mixture of diastereomers: IR (thin film) 3376, 3032, 2954, 1601, $1496 \mathrm{~cm}^{-1}$; HRMS (Cl/isobutane) $\mathrm{m} / \mathrm{z}$ calcd for $\mathrm{C}_{19} \mathrm{H}_{24} \mathrm{NO}(\mathrm{M}+\mathrm{H})^{+} 282.1858$, found 282.1862. Anal. Calcd for $\mathrm{C}_{19} \mathrm{H}_{23} \mathrm{NO}: \mathrm{C}, 81.10 ; \mathrm{H}, 8.24 ; \mathrm{N}, 4.98$. Found: $\mathrm{C}, 80.88 ; \mathrm{H}, 8.37 ; \mathrm{N}, 4.87$.

1,4-cis diastereomer 32a. ${ }^{1} \mathrm{H}$ NMR $\left(500 \mathrm{MHz}, \mathrm{CDCl}_{3}\right) \delta 7.24-7.47(\mathrm{~m}, 10 \mathrm{H}), 5.30(\mathrm{dd}, J=10.8,6.0,1 \mathrm{H}), 3.21$ (d, $J=13.6,1 \mathrm{H}), 3.02(\mathrm{~d}, J=13.6,1 \mathrm{H}), 2.18(\mathrm{dd}, J=12.4,6.0,1 \mathrm{H}), 2.12(\mathrm{t}, J=11.5,1 \mathrm{H}), 1.24(\mathrm{~s}, 3 \mathrm{H}), 1.11$ (s, $2 \mathrm{H}), 0.70(\mathrm{~s}, 3 \mathrm{H}) ;{ }^{13} \mathrm{C} \mathrm{NMR}\left(125 \mathrm{MHz}, \mathrm{CDCl}_{3}\right) \delta 143.8,142.2,128.8,128.25,127.5,126.9,126.1,125.1,91.5$, 78.9, 50.9, 49.7, 45.1, 27.0, 22.7.

1,4-trans diastereomer 32b. ${ }^{1} \mathrm{H}$ NMR $\left(500 \mathrm{MHz}, \mathrm{CDCl}_{3}\right) \delta 7.25-7.55(\mathrm{~m}, 10 \mathrm{H}), 5.15(\mathrm{dd}, J=9.8,5.4,1 \mathrm{H})$, $3.18(\mathrm{~d}, J=14.0,1 \mathrm{H}), 3.12(\mathrm{~d}, J=14.0,1 \mathrm{H}), 2.56(\mathrm{dd}, J=12.7,9.8,1 \mathrm{H}), 1.93(\mathrm{dd}, J=12.8,5.5,1 \mathrm{H}), 1.33$ (s, $2 \mathrm{H}), 1.25(\mathrm{~s}, 3 \mathrm{H}), 0.59(\mathrm{~s}, 3 \mathrm{H}) ;{ }^{13} \mathrm{C} \mathrm{NMR}\left(125 \mathrm{MHz}, \mathrm{CDCl}_{3}\right) \delta 144.4,141.5,128.6,128.33,127.1,127.0,126.2$, 125.7, 91.6, 75.4, 49.9, 45.4, 44.3, 28.8, 23.1.

Relevant DPFGSE-nOe data (mixing time 2.0 s): (the peaks in the ${ }^{1} \mathrm{H}$ NMR spectra were assigned using ${ }^{1} \mathrm{H} /{ }^{1} \mathrm{H}$ COSY, ${ }^{1} \mathrm{H}$ NMR chemical shifts, and ${ }^{1} \mathrm{H}$ NMR coupling constants)

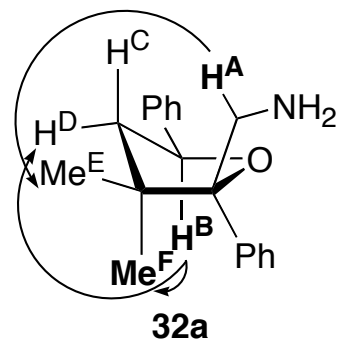

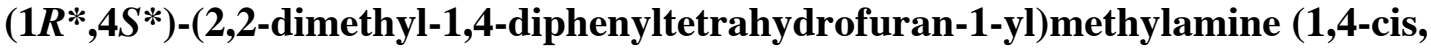
major)

nOe experiments were performed for 32a using a pure sample of the isomer

$\mathbf{H}^{\mathrm{A}}$ irradiated: $\mathrm{Me}^{\mathrm{E}}(2.5 \%)$

$\mathbf{H}^{\mathbf{B}}$ irradiated: $\mathrm{H}^{\mathrm{D}}(2.7 \%), \mathrm{Me}^{\mathrm{F}}(4.1 \%)$

$\mathbf{M e}^{\mathrm{F}}$ irradiated: $\mathrm{H}^{\mathrm{B}}(1.2 \%), \mathrm{H}^{\mathrm{D}}(4.6 \%)$

Note: The absence of nOe between $\mathrm{H}^{\mathrm{A}}$ and $\mathrm{H}^{\mathrm{B}}$ suggests a 1,4-cis configuration. 


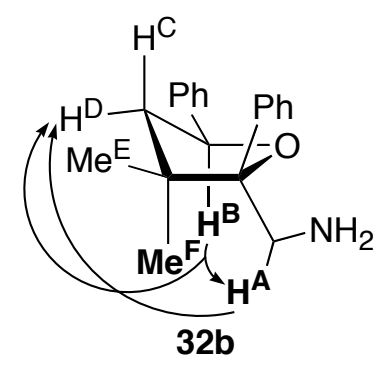

\author{
$\left(1 S^{*}, 4 S^{*}\right)$-(2,2-dimethyl-1,4-diphenyltetrahydrofuran-1-yl)methylamine (1,4-trans, \\ minor) \\ nOe experiments were performed for 32b using a pure sample of the isomer \\ $\mathbf{H}^{\mathrm{A}}$ irradiated: $\mathrm{H}^{\mathrm{B}}(15.0 \%), \mathrm{H}^{\mathrm{D}}(8.0 \%)$ \\ $\mathbf{H}^{\mathrm{B}}$ irradiated: $\mathrm{H}^{\mathrm{A}}(4.0 \%), \mathrm{H}^{\mathrm{D}}(6.0 \%)$ \\ Note: The observation of nOe between $\mathrm{H}^{\mathrm{B}}$ and $\mathrm{H}^{\mathrm{A}}$ suggests a 1,4-trans configuration.
}

\title{
IV. Bibliography
}

1. Pangborn, A. B.; Giardello, M. A.; Grubbs, R. H.; Rosen, R. K.; Timmers, F. J. Organometallics 1996, 15, $1518-1520$.

2. Rychnovsky, S. D.; Powell, N. A. J. Org. Chem. 1997, 62, 6460-6461.

3. Flores-Parra, A.; Gutierrez-Avella, D. M.; Guzman-Vazquez, Y. J.; Ariza-Castolo, A.; Contreras, R. J. Org. Chem. 1992, 57, 6067-6071.

4. Pastor, I. M.; Yus, M. Tetrahedron Lett. 2000, 41, 5335-5339.

5. Yoda, H.; Mizutani, M.; Takabe, K. Heterocycles 1998, 48, 679-686.

6. The diastereomeric ratio was determined based on the analysis of ${ }^{1} \mathrm{H}$ NMR spectra. The relative stereochemistry was determined on the basis of NOE data. (See supporting information for the stereochemical proof.)

7. Brown, H. C.; Toon, N. M. J. Am. Chem. Soc. 1966, 88, 1464-1472. 


\section{Analytical Data}

A. GC traces and ${ }^{1}$ H NMR spectra of unpurified isomer ratios
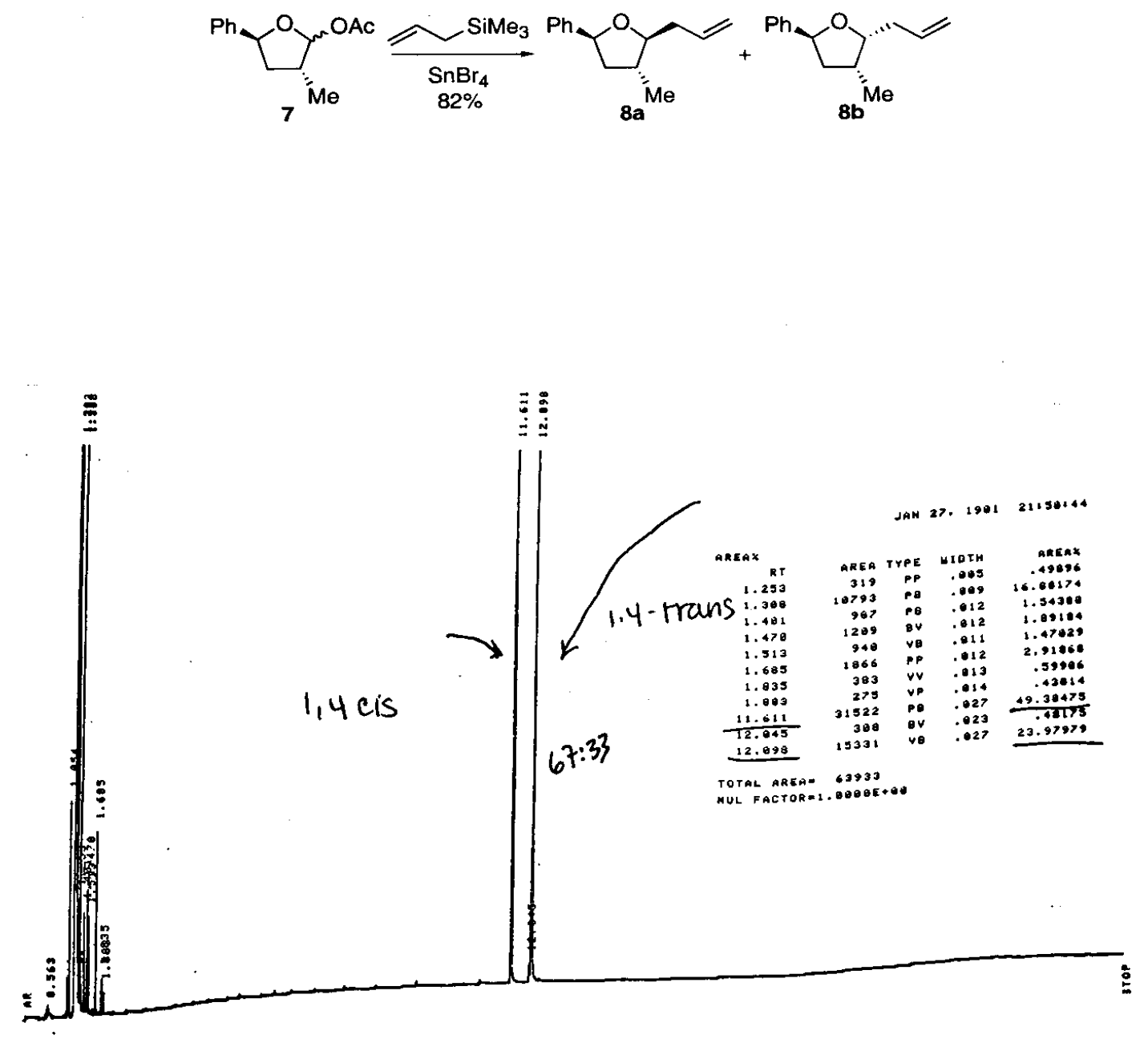

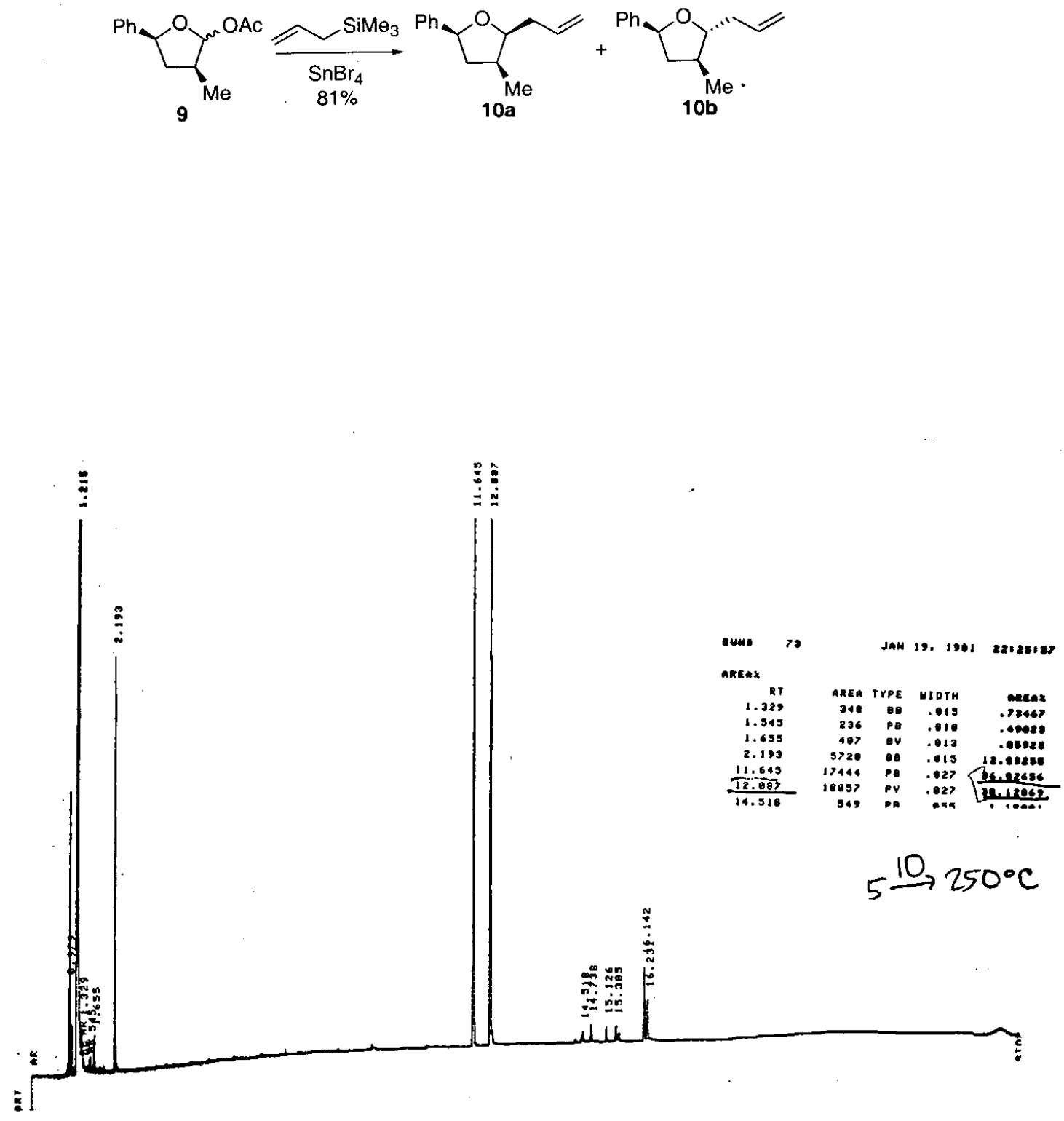
Data File C: \HPCHEM \1\DATA \DMS $\backslash 027 F 0401 . D$

dilu
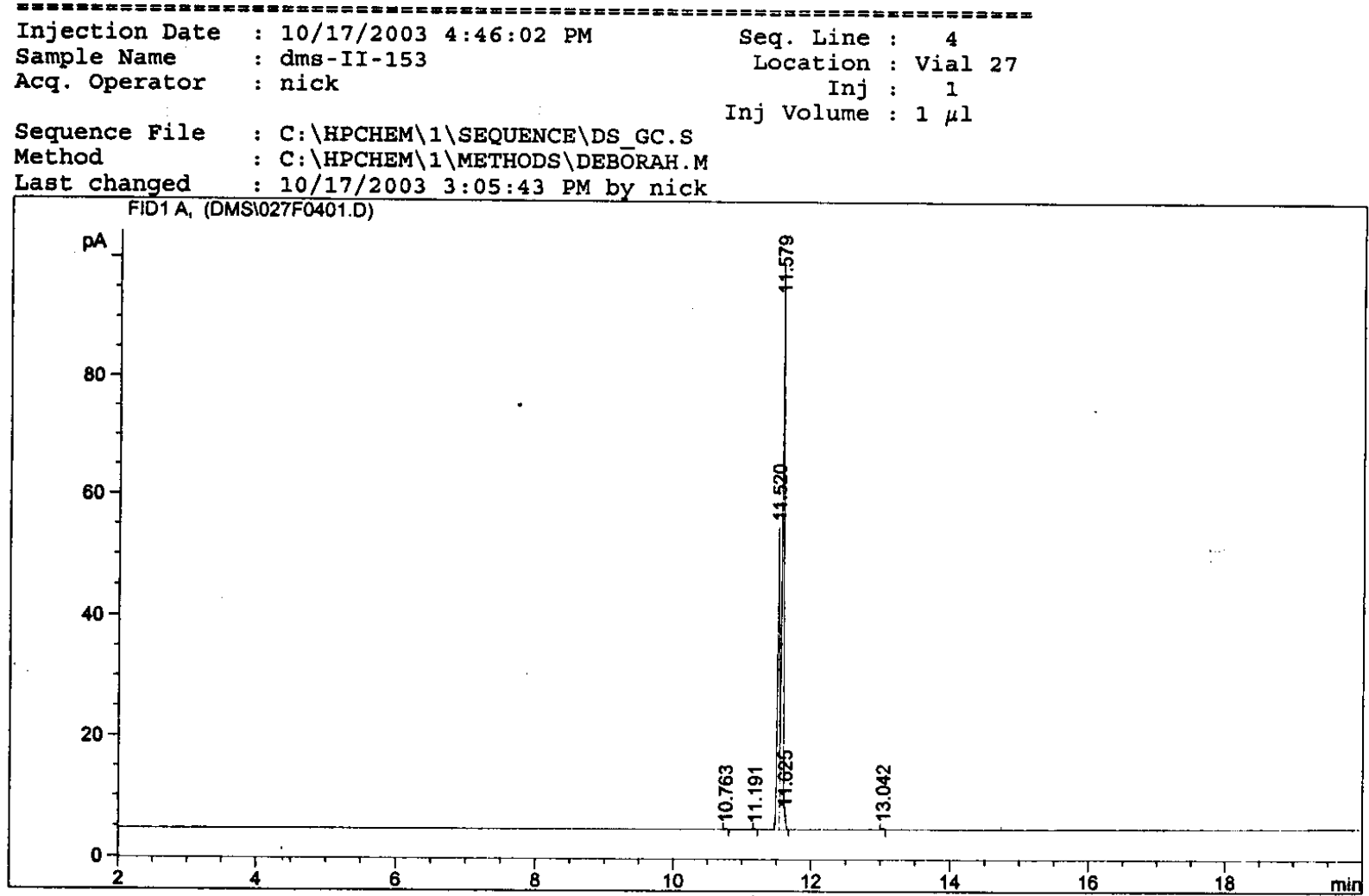

Area Percent Report

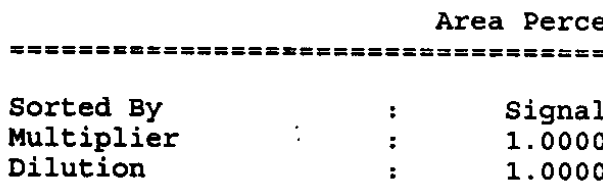

Signal 1: FID1 A,<smiles>[CH]C1CC(c2ccccc2)OC1(C)OC</smiles>

$15^{\mathrm{Me}}$

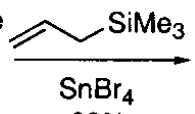

$88 \%$<smiles>C=CC[C@]1(C)O[C@@H](c2ccccc2)CC1[18OH]</smiles>

Width Area Height Area [m1n] [pA*s] [pA]

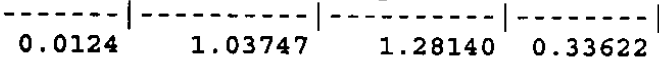
$0.0137 \quad 16.22663 \quad 18.16370 \quad 5.25860$ $\begin{array}{llll}0.0254 & 3.75290 \mathrm{e}-1 & 1.89334 \mathrm{e}-1 & 0.12162\end{array}$ $0.0228 \quad 2.16886 \mathrm{e}-1 \quad 1.21371 \mathrm{e}-1 \quad 0.07029$ $\begin{array}{lllll}0.0269 & 98.48309 & 50.19186 & 31.91563\end{array}$ $\begin{array}{llll}0.0265 & 184.57216 & 94.80299 & 59.81470\end{array}$ $\begin{array}{llll}0.0172 & 3.74642 & 2.74249 & 1.21411\end{array}$ $0.02626 .86757 \mathrm{e}-1 \quad 3.60618 \mathrm{e}-1 \quad 0.22256$ $\begin{array}{llll}0.0421 & 7.08772 \mathrm{e}-1 & 2.00139 \mathrm{e}-1 & 0.22969\end{array}$ $0.01372 .31466 \mathrm{e}-1 \quad 2.07979 \mathrm{e}-1 \quad 0.07501$ $0.03546 .22925 \mathrm{e}-1 \quad 2.14427 \mathrm{e}-1 \quad 0.20187$ $0.02668 .98104 \mathrm{e}-1 \quad 4.09270 \mathrm{e}-1 \quad 0.29105$ $0.02347 .67247 \mathrm{e}-1 \quad 4.09459 \mathrm{e}-1 \quad 0.24864$

Totals : $308.57323 \quad 169.29503$

Instrument 1 10/17/2003 5:08:03 PM nick 

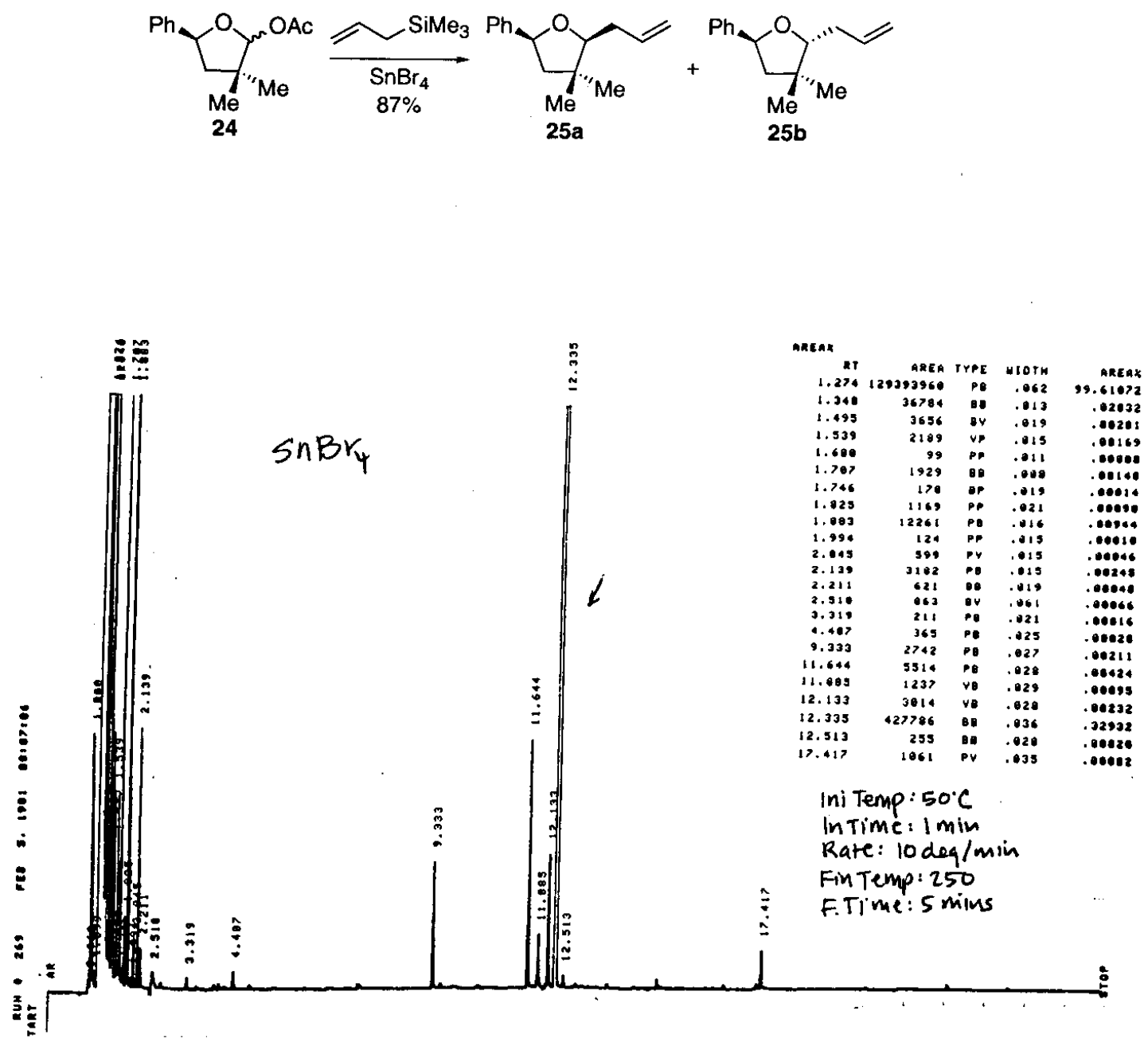


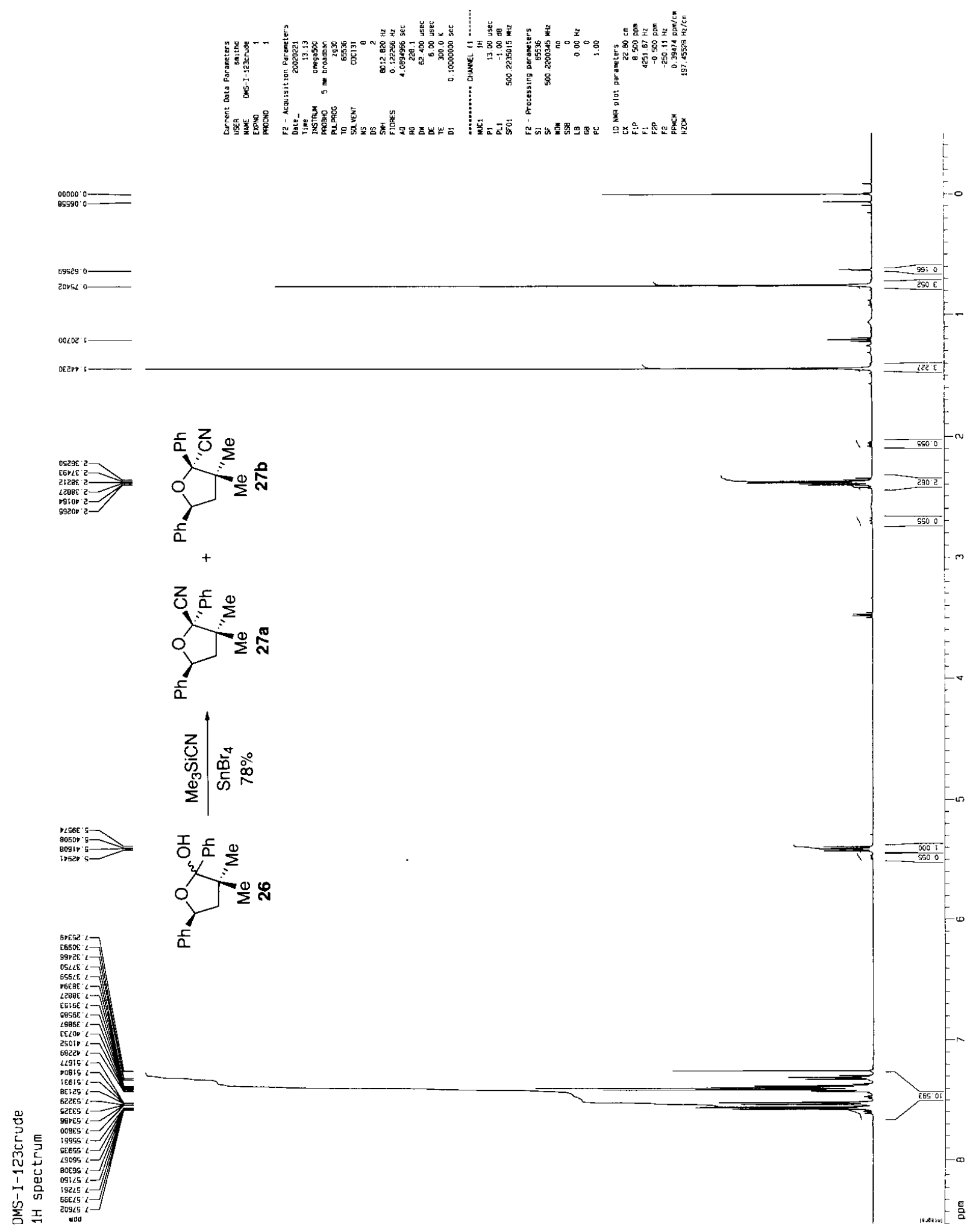




\section{B. Selected ${ }^{1} \mathrm{H}$ and ${ }^{13} \mathrm{C}$ NMR spectra}

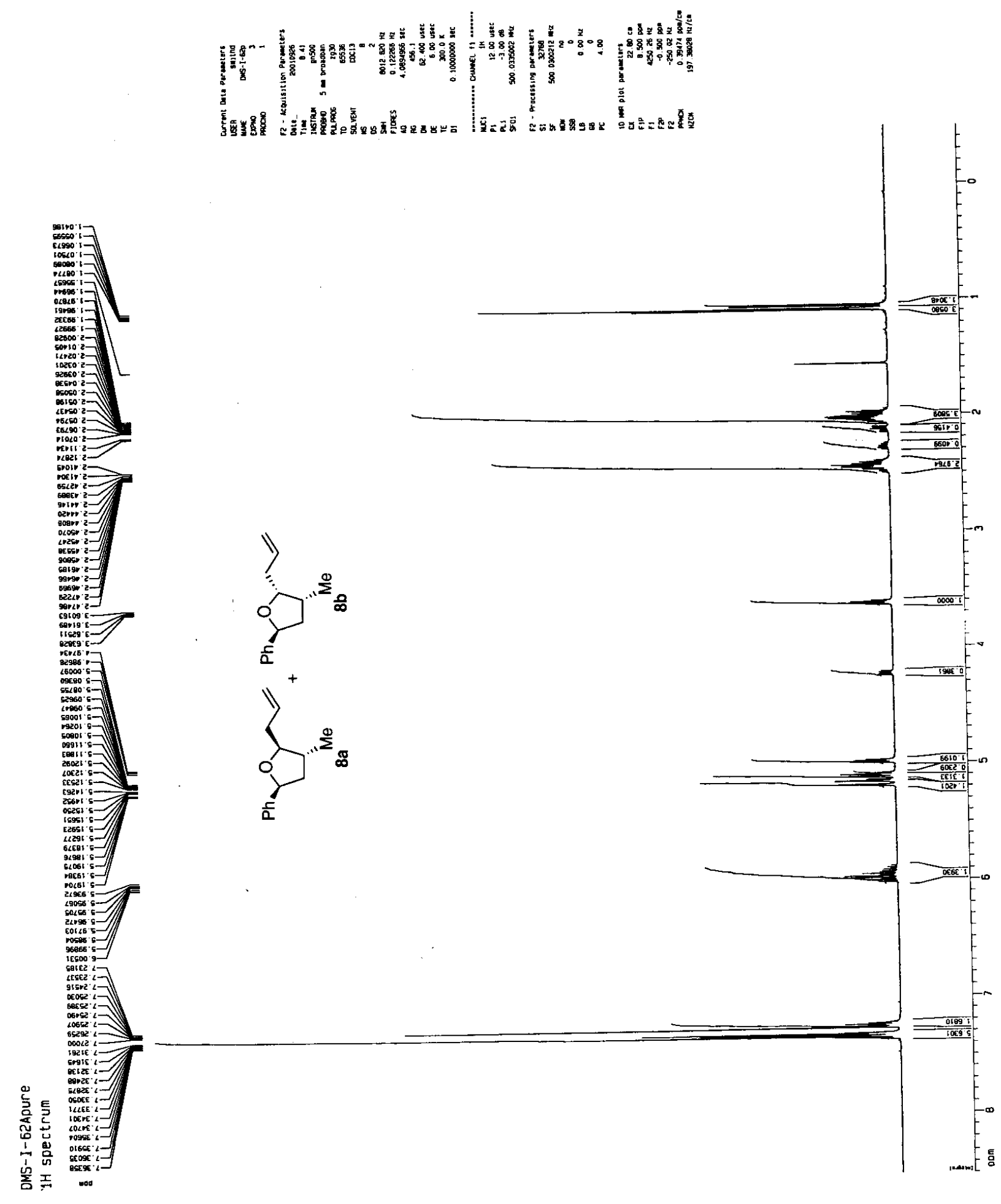




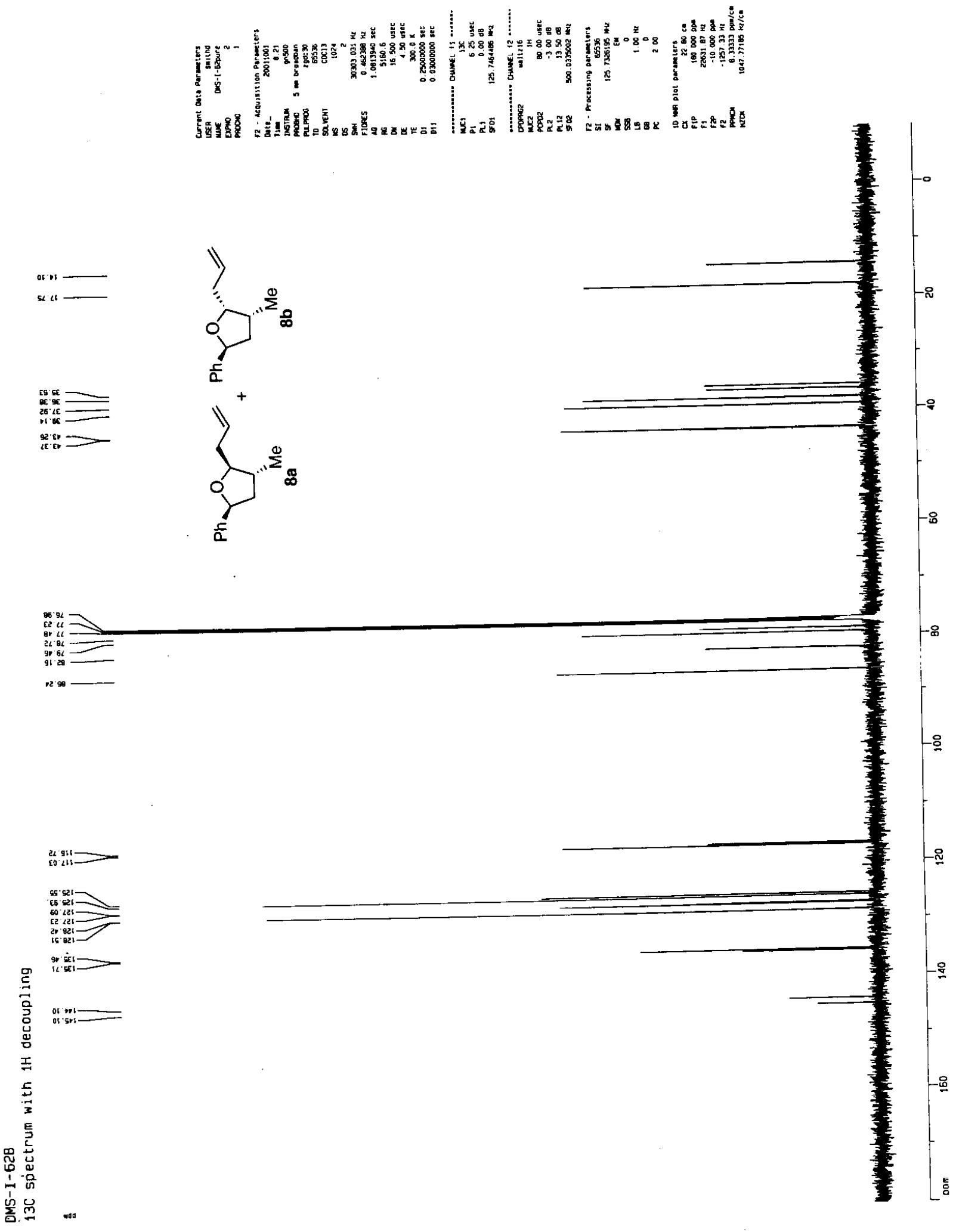




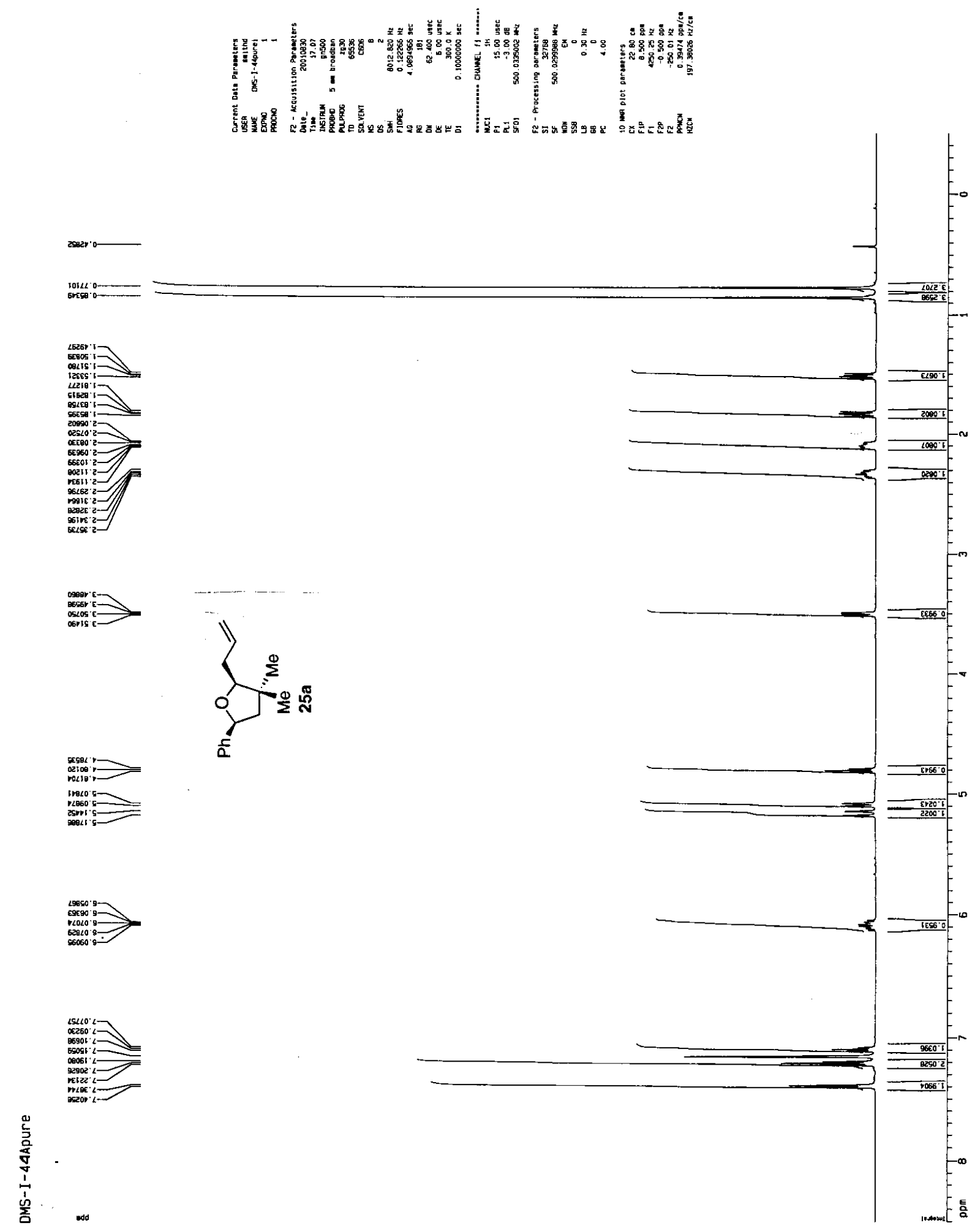



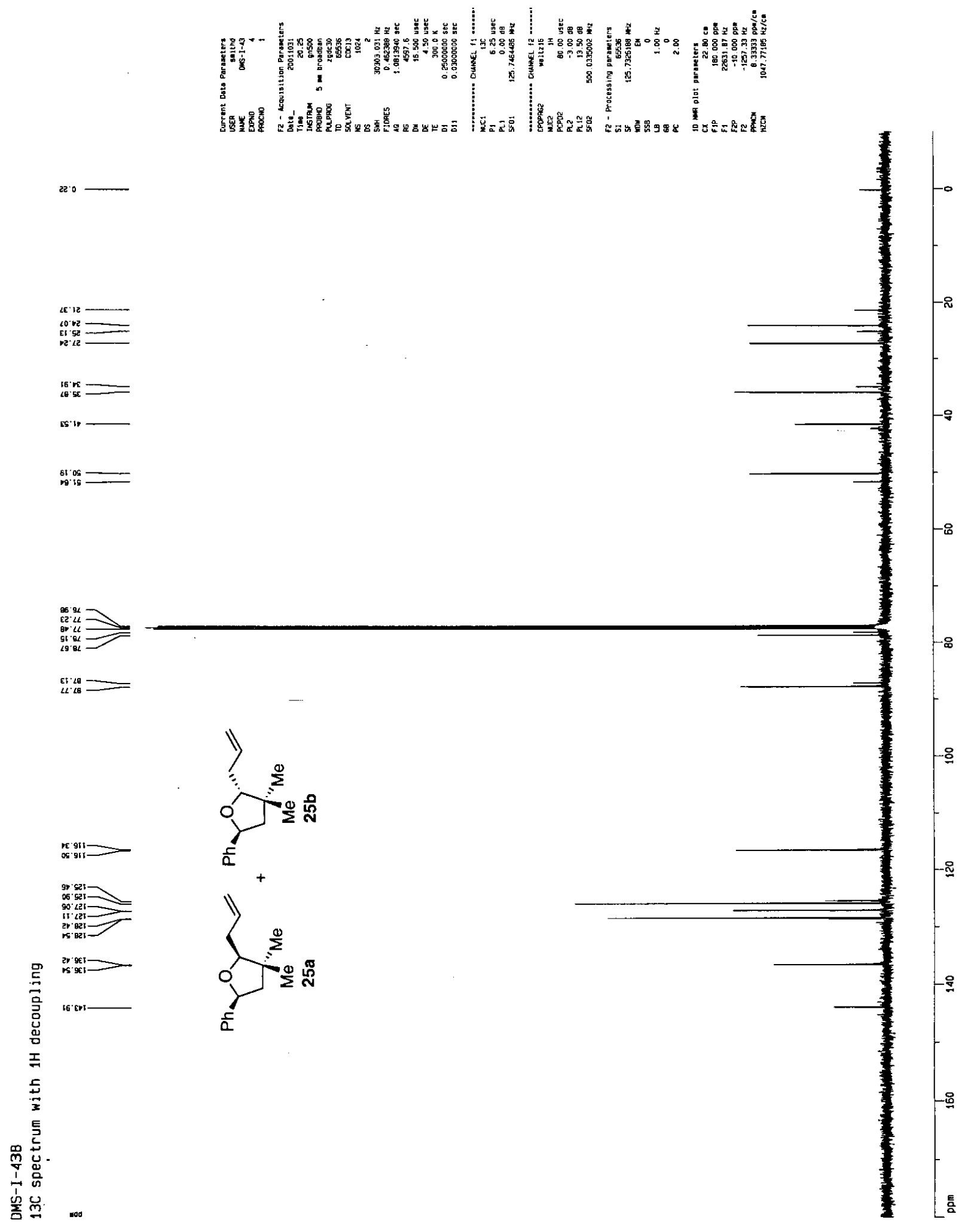